\title{
Inhibition of Calcium Channels in Rat Central and Peripheral Neurons by $\omega$-Conotoxin MVIIC
}

\author{
Stefan I. McDonough,, ${ }^{1,2}$ Kenton J. Swartz, ${ }^{1}$ Isabelle M. Mintz, ${ }^{1}$ Linda M. Boland, ${ }^{1}$ and Bruce P. Bean ${ }^{1,2}$ \\ 'Department of Neurobiology, Harvard Medical School, Boston, Massachusetts 02115, and 2Vollum Institute, Oregon \\ Health Sciences University, Portland, Oregon 97201
}

Inhibition of voltage-dependent calcium channels by $\omega$-conotoxin MVIIC ( $\omega$-CTX-MVIIC) was studied in various types of rat neurons. When studied with $5 \mathrm{mM} \mathrm{Ba}^{2+}$ as charge carrier, $\omega$-CTX-MVIIC block of $\mathrm{N}$-type calcium channels in sympathetic neurons was potent, with half-block at $18 \mathrm{~nm}$. Block of $\mathrm{N}$-type channels had a rapid onset $(\tau \sim 1 \mathrm{sec}$ at $1 \mu \mathrm{M} \omega$-CTx-MVIIC) and quick reversibility $(\tau \sim 30 \mathrm{sec})$. The rate of block was proportional to toxin concentration, consistent with 1:1 binding of toxin to channels, with a rate constant $\left(k_{\text {on }}\right)$ of $\sim 1 \times 10^{6} \mathrm{M}^{-1}$. $\mathrm{sec}^{-1}$. Both potency and rate of block were reduced dramatically with increasing concentrations of extracellular $\mathrm{Ba}^{2+}$. $\omega$-CTx-MVIIC also blocked P-type calcium channels in cerebellar Purkinje neurons, but both development and reversal of block were far slower than for N-type channels. The rate of block was proportional to toxin concentration, with $k_{\text {on }} \sim 1.5 \times$ $10^{3} \mathrm{~m}^{-1} \cdot \mathrm{sec}^{-1}$ at $5 \mathrm{~mm} \mathrm{Ba}^{2+}$. From this value and an unblocking time constant of $\sim 200 \mathrm{~min}$, a dissociation constant of $\sim 50$ nM was estimated. Thus, block of P-type channels is potent but very slow. In hippocampal CA3 pyramidal neurons, $\omega$-CTXMVIIC blocked $\sim 50 \%$ of the high-threshold calcium channel current; one component ( $20 \%)$ was blocked with the rapid kinetics expected for $\mathrm{N}$-type channels, whereas the other component was blocked slowly. The component blocked slowly was reduced but not eliminated by preexposure to $200 \mathrm{~nm}$ or 1 $\mu \mathrm{M} \omega$-Aga-IVA.

Key words: calcium channels; w-conotoxin MVIIC; Purkinje neuron; sympathetic ganglion; hippocampus; $\omega$-Aga-IVA
Naturally occurring peptide toxins are useful for distinguishing among different types of calcium channels. Several known toxins are highly selective. $\omega$-conotoxin GVIA, from the cone snail Conus geographus (Olivera et al., 1984), potently and selectively inhibits "N-type" channels, which contribute most of the calcium current in sympathetic neurons and a smaller fraction in most other neurons (Jones and Marks, 1989; Regan et al., 1991; Boland et al., 1994). Channels expressed from cloned $\alpha_{1 \mathrm{~B}}$ subunits are blocked potently by $\omega$-conotoxin GVIA and are identified with N-type channels (Williams et al., 1992; Fujita et al.,1993; Stea et al., 1993). Another selective toxin is $\omega$-Aga-IVA, a spider toxin that potently blocks the "P-type" channels that predominate in Purkinje neurons (Mintz et al., 1992b) but has no effect on N-type channels or on dihydropyridine-sensitive L-type channels (Mintz et al., 1992a). This toxin may be less selective than (n-conotoxin GVIA, because weak block of a component of current in cerebellar granule neurons has been reported (Randall and Tsien, 1995). No cloned channels are known to be blocked by $\omega$-Aga-IVA with high potency, but channels expressed by $\alpha_{1 \mathrm{~A}}$ subunits are blocked weakly (Sather et al., 1993; Stea et al., 1994).

Toxins that have blocking activity against components of calcium current resistant to the well characterized blockers should be

\footnotetext{
Received June 24. 1995; revised Feb. 1, 1996; accepted Feb. 2, 1996.

This research was supported by National Institutes of Health (HL35034). We thank Dis. George Miljanich and Baldomero Olivera for furnishing $\omega$-CTx-MVIIC for early experiments.

Correspondence should be addressed to Bruce P. Bean, Vollum Institute, L-474, Oregon Health Sciences University, 3181 SW Sam Jackson Park Road, Portland, OR 97201.

Dr. Mintz's present address: Department of Pharmacology, Boston University School of Medicine, 80 East Concord Street, Boston, MA 02118.

Dr. Boland's present address: Department of Physiology, University of Minnesota, Minneapolis, MN 55455.

Copyright (C) 1996 Society for Neuroscience $0270-6474 / 96 / 162612-12 \$ 05.00 / 0$
}

useful in further characterizing calcium channels in central neurons. One such toxin is $\omega$-conotoxin-MVIIC ( $\omega$-CTx-MVIIC), identified from a cDNA library from the venom gland of the snail Conus magus (Hillyard et al., 1992). When the peptide coded by the cDNA was synthesized, it proved to have blocking activity against mammalian calcium channels. In hippocampal CA1 neurons, $\omega$-CTx-MVIIC blocked not only N-type current sensitive to $\omega$-conotoxin GVIA but other components as well, and it also inhibited P-type channels in Purkinje neurons (Hillyard et al,, 1992). The toxin also blocks channels formed by $\alpha_{1 \mathrm{~A}}$ subunits expressed in Xenopus oocytes (Sather et al., 1993; Zhang et al., 1993, Stea et al., 1994; DeWaard and Campbell, 1995), and it apparently targets calcium channels that contribute to synaptic transmission but are resistant to both GVIA (Wheeler et al., 1994) and (o-Aga-IVA (Lovinger et al., 1994; Wu and Saggau, 1995a).

Because $\omega$-CTX-MVIIC inhibits multiple types of channels, it is important to establish the concentration-dependence and kinetics for inhibition of particular channels. Our principal goal was to characterize the potency and kinetics of $\omega$-CTx-MVIIC block of $\mathrm{N}$-type and P-type channels, which can be studied as the predominant channel types in rat sympathetic neurons and Purkinje neurons, respectively. We found that the toxin blocks both channel types with high potency but with very different kinetics. In hippocampal neurons, $\omega$-CTx-MVIIC blocked multiple components of current, including a component that was insensitive to $\omega$-conotoxin GVIA, nimodipine, and $1 \mu \mathrm{M} \omega$-Aga-IVA. Knowledge of the characteristics for block of particular channel types will be useful in the further use of the toxin to disrupt functions of calcium channcls such as synaptic transmission.

\section{MATERIALS AND METHODS}

Cell preparation. Purkinje neurons and hippocampal CA3 pyramidal neurons were isolated from the brains of 6- to 21 -d-old Long-Evans rats by 
using solutions modified from those of Furshpan and Potter (1989) and enzyme treatment like that of Kiskin et al. (1990). Brain tissue was dissected out in ice-cold "dissociation solution" consisting of $82 \mathrm{~mm}$ $\mathrm{Na}_{2} \mathrm{SO}_{4}, 30 \mathrm{mM} \mathrm{K}_{2} \mathrm{SO}_{4}, 5 \mathrm{~mm} \mathrm{MgCl}, 10 \mathrm{~mm}$ HEPES, $10 \mathrm{~mm}$ glucose, and $0.001 \%$ phenol red indicator, $\mathrm{pH} 7.4$, adjusted with $\mathrm{NaOH}$. Cerebellum or hippocampus was cut with a tissue chopper into $400 \mu \mathrm{M}$ thick slices. The slices were transferred into the dissociation solution with $3 \mathrm{mg} / \mathrm{ml}$ protease XXIII (Sigma, St. Louis, MO) and incubated at $37^{\circ} \mathrm{C}$ for $7-8$ $\mathrm{min}$. The slices were then rinsed twice in the dissociation solution at $37^{\circ} \mathrm{C}$ with added $1 \mathrm{mg} / \mathrm{ml}$ trypsin inhibitor (Sigma) and $1 \mathrm{mg} / \mathrm{ml}$ bovine serum albumin (Sigma), pH 7.4, adjusted with $\mathrm{NaOH}$. After enzyme treatment, slices were stored in the dissociation solution (with trypsin inhibitor and bovine serum albumin) at $22^{\circ} \mathrm{C}$ under an oxygen atmosphere. As cells wère needed, slices were withdrawn (and the CA3 region dissected, in the case of hippocampal slices) and triturated $(\sim 20$ passages through the tip of a fire-polished Pasteur pipette) to release cells. Purkinje neurons were identified morphologically by their large cell bodies $(15-25 \mu \mathrm{m}$ diameter) with a single dendritic stump.

Rat superior cervical ganglion (SCG) neurons were prepared by following a modification of the protocol of Bernheim et al. (1991). Ganglia were dissected from 15- to 21-d-old rats in Leibovitz's L-15 medium (Life Technologies, Gaithersburg, MD) incubated at $35^{\circ} \mathrm{C}$ for 20 min under an $\mathrm{O}_{2}$ atmosphere in a solution containing $25 \mathrm{U} / \mathrm{ml}$ papain (Worthington Biochemicals, Freehold, NJ), $0.5 \mathrm{~mm}$ EDTA, $2 \mathrm{~mm}$ cysteine, $150 \mathrm{~mm}$ $\mathrm{NaCl}, 4 \mathrm{mM} \mathrm{KCl}, 2 \mathrm{~mm} \mathrm{MgCl}, 10 \mathrm{~mm}$ glucose, and $10 \mathrm{~mm}$ HEPES, $\mathrm{pH}$ 7.4. They were then transferred into a solution with $2 \mathrm{mg} / \mathrm{ml}$ collagenase (Type I, Sigma), $16 \mathrm{mg} / \mathrm{ml}$ dispase (grade II; Boehringer Mannheim, Indianapolis, IN), $150 \mathrm{mM} \mathrm{NaCl}, 4 \mathrm{~mm} \mathrm{KCl}, 2 \mathrm{mM} \mathrm{MgCl}_{2}, 10 \mathrm{~mm}$ glucose, and $10 \mathrm{~mm}$ HEPES, $\mathrm{pH} 7.4$, for $45 \mathrm{~min}$ at $35^{\circ} \mathrm{C}$ under oxygenation. Ganglia were stored for up to $6 \mathrm{hr}$ at $4^{\circ} \mathrm{C}$ in oxygenated Leibovitz's medium. When needed, SCG neurons were released from ganglia by gentle trituration through a Pasteur pipette tip.

Electrophysiological methods. Currents through voltage-activated calcium channels were recorded using the whole-cell configuration of the patch-clamp technique (Hamill et al., 1981). Patch pipettes were made from borosilicate glass tubing (Boralex, Dynalab, Rochester, NY) or R-6 glass (Garner Glass, Claremont, CA) coated with Sylgard (Dow Corning, Midland, MI) and fire-polished. Pipettes had resistances of 1-4 M $\Omega$ when filled with internal solution. Currents were recorded with a List EPC-7 (Medical Systems, Greenvale, NY) or an Axopatch 200A (Axon Instruments, Foster City, CA) patch-clamp amplifier. Currents were filtered with a corner frequency of $1-10 \mathrm{kHz}$ (4-pole Bessel filter), digitized $(10-25 \mathrm{kIIz})$ using a BASIC-FastLab interface and software (Indec Systems, Sunnyvale, CA) or a Digidata 1200 interface and Pclamp6 software (Axon Instruments), and stored on a computer. Compensation (typically $80-95 \%$ ) for series resistance (typically $\sim 2.5$ times higher than the pipette resistance) was used. Only data from cells with residual series resistance and current small enough to give a voltage error of $<5 \mathrm{mV}$ were analyzed. Calcium channel currents were elicited by test pulses to a voltage near that giving peak inward current for the particular cell type and the external solution being used. $\omega$-CTX-MVIIC block in sympathetic and Purkinje neurons showed no voltage-dependence, with currents inhibited equally well at all voltages. Calcium channel currents were corrected for leak and capacitive currents, either by applying $300 \mu \mathrm{M} \mathrm{CdCl}_{2}$ to block calcium channel current or by subtracting a scaled current elicited by a $10 \mathrm{mV}$ hyperpolarization from $-80 \mathrm{mV}$. In some cases, particularly with hippocampal neurons, when test pulses were near $0 \mathrm{mV}$ it was more accurate to measure current during the test pulse without leak correction, because linear extrapolation of leak current between -80 $\mathrm{mV}$ and $-90 \mathrm{mV}$ obviously predicted too much outward leak, and leak current reverses very near $0 \mathrm{mV}$ (Swartz and Bean, 1992).

All experiments were performed at $20-25^{\circ} \mathrm{C}$. Statistics are given as mean \pm SEM unless noted otherwise.

Solutions. Unless noted otherwise, the internal solution was $122 \mathrm{~mm}$ tetraethylammonium chloride (TEACl), $4.5 \mathrm{mM} \mathrm{MgCl}_{2}, 9 \mathrm{mM}$ EGTA, 9 mM HEPES, $4 \mathrm{~mm} \mathrm{Mg-ATP,} 14 \mathrm{~mm}$ creatine phosphate (Tris salt), 0.3 mM GTP (Tris salt), $\mathrm{pH} 7.4$, adjusted with TEAOH. In some experiments with sympathetic neurons, the internal solution contained $108 \mathrm{mM}$ cesium methanesulfonate rather than $122 \mathrm{~mm} \mathrm{TEACl}$; in these experiments, the reported voltages are corrected for a junction potential of $-10 \mathrm{mV}$ between the internal solution and the Tyrode's solution in which current was zeroed before forming a seal. There was no obvious difference between the two internal solutions in the characteristics of calcium channel currents or block by $\omega$-CTx-MVIIC. The standard external solution contained $5 \mathrm{~mm} \mathrm{BaCl}, 160 \mathrm{~mm}$ TEACl, $10 \mathrm{~mm}$ HEPES, $1 \mathrm{mg} / \mathrm{ml}$ cytochrome $\mathrm{C}$ (Sigma), $\mathrm{pH} 7.4$, adjusted with TEAOH. To isolate $\mathrm{N}$-type current in sympathetic neurons, solutions contained $10 \mu \mathrm{M}$ nimodipine, and to isolate P-type current in Purkinje neurons, solutions contained 5-10 $\mu \mathrm{M}$ nimodipine and $1 \mu \mathrm{M} \omega$-conotoxin GVIA. In some experiments, as noted, $2 \mathrm{mM}$ or $25 \mathrm{mM} \mathrm{BaCl}_{2}$ were used ( $\mathrm{TEACl}$ was reduced to 145 mM when $25 \mathrm{mM} \mathrm{BaCl}_{2}$ was used). In a few experiments, $1 \mu \mathrm{M}$ tetrodotoxin was present in the cxtcrnal solution and had no effect on the results. In experiments using $\mathrm{Ca}^{2+}$ as charge carrier, the external solution was 2 $\mathrm{mm} \mathrm{CaCl}, 2 \mathrm{~mm} \mathrm{MgCl}, 1 \mathrm{~mm}$ TEACl, $154 \mathrm{~mm} \mathrm{NaCl}, 10 \mathrm{~mm}$ glucose, 10 mM HEPES, $1 \mu \mathrm{M}$ tetrodotoxin, $\mathrm{pH} 7.4$, adjusted with $\mathrm{NaOH}$. External solutions were exchanged in $<1 \mathrm{sec}$ by moving the cell between continuously flowing solutions from 140 or $250 \mu \mathrm{m}$ diameter capillary tubes.

Stock solutions for drugs were 0.5 or $1 \mathrm{~mm} \omega$-conotoxin GVIA (Peninsula Laboratories, Belmont, $\mathrm{CA}$ ) in the recording $\mathrm{Ba}^{2+}$ solution, 3 or 10 mm nimodipine (a gift from Dr. Richard McCarthy, Miles Laboratories, West Haven, CT) in polyethylene glycol 400 (Sigma), $100 \mu \mathrm{M}$ synthetic $\omega$-Aga-IVA (Peptides International, Louisville, $\mathrm{KY}$ ) in $\mathrm{H}_{2} \mathrm{O}, 1 \mathrm{~mm}$ $\omega$-CTx-MVIIC (Bachem California, Torrance, CA, or Peptides International, Louisville, KY) in $\mathrm{H}_{2} \mathrm{O}$. Drug-containing stock solutions were stored frozen at $-20^{\circ} \mathrm{C}$, and all were stable for months. Drug-containing recording solutions were usually made the day of the experiment; sumetimes they were used the following day after storage overnight at room temperature, with no loss of potency.

\section{RESULTS}

\section{Dose dependence and kinetics}

Figure 1 shows the effect of $2 \mu \mathrm{M} \omega$-CTX-MVIIC applied to a sympathetic neuron and a Purkinje neuron under identical ionic conditions, with current carried by $5 \mathrm{mM} \mathrm{Ba}^{2+}$. In the experiment on the sympathetic neuron, L-type current (typically only 5-10\%) (Regan et al., 1991; Mintz et al., 1992a) was blocked by $10 \mu \mathrm{M}$ nimodipine (present in all external solutions). Addition of $\omega$-CTXMVIIC at $2 \mu \mathrm{M}$ blocked $\sim 85 \%$ of the current elicited by a step to $-10 \mathrm{mV}$, near the peak of the current-voltage relationship. Block was maximal within $4 \mathrm{scc}$ and reversed within a few minutes of washing out the toxin. In this and other sympathetic neurons (Figs. 2, 5), reversal of block was nearly complete, taking into account slow run-down of current in some cells.

$\omega$-CTX-MVIIC also blocked calcium channel current in cerebellar Purkinje neurons, but the kinetics of block was very different. In the experiment shown in Figure $1 B$, all solutions contained $10 \mu \mathrm{M}$ nimodipine and $1 \mu \mathrm{M} \omega$-conotoxin GVIA to block the small L-type and N-type currents present in Purkinje neurons (Mintz et al., 1992a). The addition of $2 \mu \mathrm{M} \omega$-CTX-MVIIC blocked the P-type current in the cell completely, but development of block was slow, taking $\sim 25$ min to reach completion (Fig. 1B). The reversal of block was also much slower in Purkinje neurons than in sympathetic neurons, with only a minimal recovery of current in 28 min for the cell in Figure $1 B$.

Figure $2 A$ shows the dose-dependent block of the current in a sympathetic neuron by concentrations of $\omega$-CTx-MVIIC from 3.2 nM to $10 \mu \mathrm{M}$. In this experiment, performed with $5 \mathrm{mM} \mathrm{Ba}^{2+}$ as charge carrier, block was about half-maximal at $16 \mathrm{~nm}$ toxin. Block was maximal ( $\sim 90 \%)$ at $400 \mathrm{~nm}$ toxin, and increasing the concentration to 2 or $10 \mu \mathrm{M}$ had no further effect. Figure $2 B$ shows collected results from experiments on sympathetic neurons studied with $5 \mathrm{mM} \mathrm{Ba}^{2+}$ (all in the presence of $10 \mu \mathrm{M}$ nimodipine). The dose-response relationship could be fit well by assuming that toxin binds to channels in a 1:1 manner with an equilibrium dissociation constant of $18 \mathrm{nM}$, with an average of $87 \%$ of the current (measured at -10 or $0 \mathrm{mV}$, near the peak of the currentvoltage relationship) being contributed by channels sensitive to the toxin.

Figure 3 shows the kinetics of block and recovery from block by different concentrations of $\omega$-CTX-MVIIC applied to a sympathetic neuron. The kinetic behavior was consistent with that ex- 

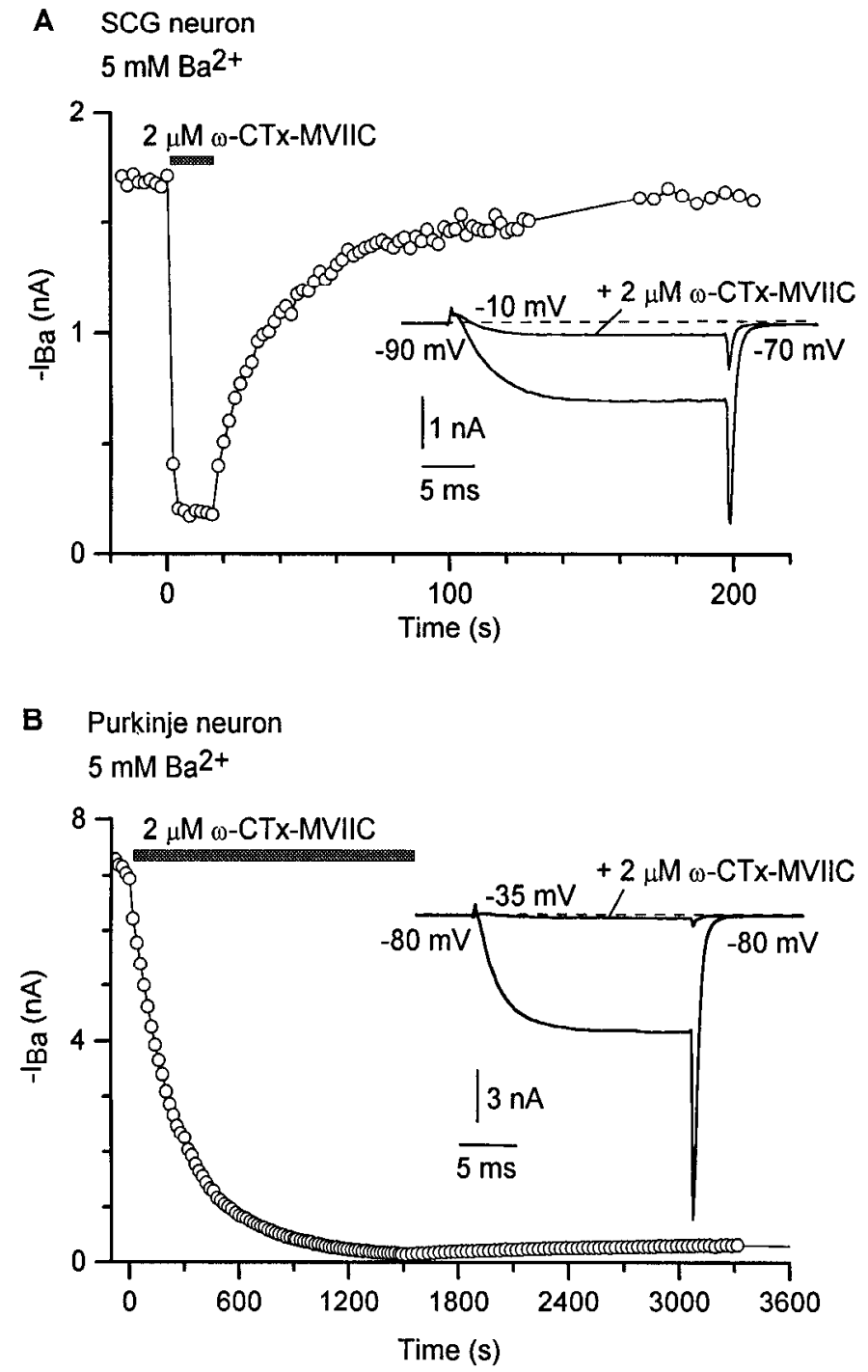

Figure 1. Block by $2 \mu \mathrm{M} \omega$-CTx-MVIIC of currents carried by $5 \mathrm{mM} \mathrm{Ba}^{2+}$ in an SCG neuron and a Purkinje neuron. $A$, Current in an SCG neuron was elicited every $2 \mathrm{sec}$ by a $30 \mathrm{msec}$ step from $-90 \mathrm{mV}$ to $-10 \mathrm{mV}$. Inset, Currents just before and $10 \mathrm{sec}$ after application of toxin. External solution: $5 \mathrm{~mm} \mathrm{BaCl}, 160 \mathrm{mM}$ TEACl, $10 \mathrm{mM}$ HEPES, pH 7.4, adjusted with TEAOH, $10 \mu \mathrm{M}$ nimodipine, $1 \mathrm{mg} / \mathrm{ml}$ cytochrome C. Internal solution: 108 mM cesium methanesulfonate, $4.5 \mathrm{~mm} \mathrm{MgCl}, 9$ mM EGTA, 9 mM HEPES, $4 \mathrm{~mm} \mathrm{Mg-ATP}, 14 \mathrm{~mm}$ creatine phosphate (Tris salt), $0.3 \mathrm{~mm}$ GTP (Tris salt), $\mathrm{pH} 7.4$, adjusted with $\mathrm{CsOH}$. $B$, Current in a Purkinje neuron was elicited every $20 \mathrm{sec}$ by a $20 \mathrm{msec}$ step from -80 to $-35 \mathrm{mV}$. Inset, Currents just before and $27 \mathrm{~min}$ after application of $\omega$-CTx-MVIIC. External solution: $5 \mathrm{~mm} \mathrm{BaCl}_{2}, 160 \mathrm{~mm} \mathrm{TEACl,} 10 \mathrm{~mm}$ HEPES, pH 7.4, adjusted with TEAOH, $10 \mu \mathrm{M}$ nimodipine, $1 \mu \mathrm{M} \omega$-conotoxin GVIA, 1 $\mathrm{mg} / \mathrm{ml} \mathrm{cytochrome} \mathrm{C.}$

pected from simple 1:1 binding. The development of block could be fit well by a single exponential (Fig. $3 A$ ), and the rate constant for development of block was related linearly to toxin concentration (Fig. 3C), with a slope giving a first-order rate constant for toxin hinding $\left(k_{\mathrm{on}}\right)$ of $1.0 \times 10^{6} \mathrm{M}^{-1} \cdot \mathrm{sec}^{-1}$. The rate of recovery from block showed no consistent dependence on toxin concentration (Fig. $3 B$ ), with a value of $4.0 \times 10 \mathrm{M}^{-2} \cdot \mathrm{sec}^{-1}$ (Fig. $3 D$ ). In collected results from six cells, most with determinations for $16 \mathrm{~nm}$ and $80 \mathrm{~nm}$ toxin, a linear regression like that in Figure $3 C$ yielded a slope of $1.08 \times 10^{6} \mathrm{M}^{-1} \cdot \mathrm{sec}^{-1}\left(\mathrm{SD} 0.02 \times 10^{6} \mathrm{M}^{-1} \cdot \mathrm{sec}^{-1}\right)$ and $y$-intercept of $0.025 \mathrm{sec}^{-1}$ (SD $\left.0.011 \mathrm{sec}^{-1}\right)$. The average off-rate

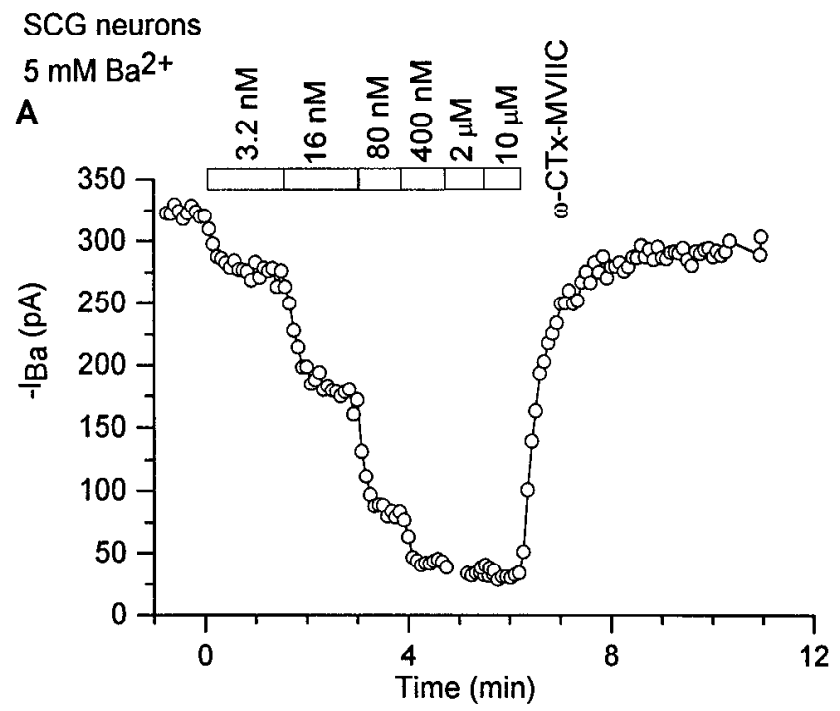

B

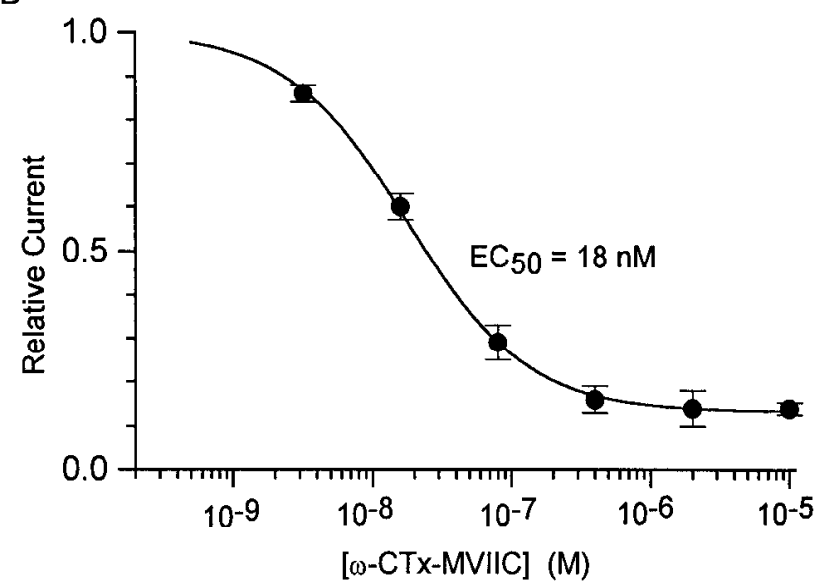

Figure 2. Dose-response relationship for $\omega$-CTx-MVIIC block of current carried by $5 \mathrm{mM} \mathrm{Ba}^{2+}$ in SCG neurons. $A$, Successive addition of increasing concentrations of $\omega$-CTx-MVIIC to an SCG neuron. Current was elicited every $5 \mathrm{sec}$ by a $30 \mathrm{msec}$ step from $-90 \mathrm{mV}$ to $-10 \mathrm{mV} . B$, Collected results from experiments like those in $A$ and others in which a single concentration of $\omega$-CTx-MVIIC was applied. Mean \pm SEM is plotted for applications of $3.2 \mathrm{~nm}$ ( 5 cells $), 16 \mathrm{nM}$ ( 5 cells), $80 \mathrm{nM}$ ( 5 cells), $400 \mathrm{nM}(5$ cells $), 2 \mu \mathrm{M}$ ( 8 cells), and $10 \mu \mathrm{M}$ ( 5 cells) toxin. Solutions as in Figure $1 A(10 \mu \mathrm{M}$ nimodipine in all external solutions). Solid line, $0.13+$ $0.87 /(1+[\omega$-CTx-MVIIC $] / 18 \mathrm{nM})$.

$\left(k_{\text {off }}\right)$, determined in 12 cells as the reciprocal of the time constant of recovery, was $0.032 \pm 0.003 \mathrm{sec}^{-1}$. The dissociation constant ( $\left.k_{\text {off }} / k_{\text {on }}\right)$ predicted from these rate constants is $30 \mathrm{nM}$, somewhat higher than the $\mathrm{EC}_{50}$ value of $18 \mathrm{~nm}$ estimated from the doseresponse experiments summarized in Figure 2.

Figure 4 shows the effects of different concentrations of toxin on the current carried by $5 \mathrm{mM} \mathrm{Ba}^{2+}$ in Purkinje neurons. It was not feasible to determine an equilibrium dose-response curve for block of current in Purkinje neurons because of the slow development of block. Block by $2 \mu \mathrm{M}$ toxin was complete but took $20-30 \mathrm{~min}$ to reach completion (Figs. $1 B, 4 A$ ). It would be difficult to reach equilibrium block with significantly lower concentrations, because it is difficult to record stable currents regularly from a cell for more than $1 \mathrm{hr}$. We therefore tried to estimate the strength of binding of toxin to the channels in Purkinje neurons by using a kinetic analysis. The time course of development of block by concentrations of $2 \mu \mathrm{M}$ or higher could be fit well by a single 



Figure 3. Blocking kinetics in SCG neurons with $5 \mathrm{~mm} \mathrm{Ba}^{2+}$. A, Time course of block by different concentrations of $\omega$-CTx-MVIIC applied to an SCG neuron. Currents were normalized to that just before toxin application. Currents were elicited by a $30 \mathrm{msec}$ step from $-90 \mathrm{mV}$ to $-10 \mathrm{mV}$ ( $15 \mathrm{msec}$ step for the application of $2 \mu \mathrm{M}$ toxin) delivered every $5 \sec (16$ $\mathrm{nM}), 1 \mathrm{sec}(400 \mathrm{nM}, 80 \mathrm{nM})$, or $0.5 \mathrm{sec}(2 \mu \mathrm{M})$. Solid lines are single exponentials with indicated time constants. $B$, Time course of recovery from different concentrations of toxin. Same cell as $A$, but different runs of toxin application, all with $30 \mathrm{msec}$ steps to $-10 \mathrm{mV}$ delivered every $5 \mathrm{sec}$. Currents are normalized to current at time of maximum recovery. Solid lines are single exponentials with time constants of $18 \mathrm{sec}(16 \mathrm{nM}), 22 \mathrm{sec}$ $(80 \mathrm{~nm}), 27 \mathrm{sec}(400 \mathrm{~nm})$, and $23 \mathrm{sec}(2 \mu \mathrm{M})$. C, The reciprocal of the time constant for development of block is plotted versus toxin concentration. Fitted line has slope of $1.05 \times 10^{6} \mathrm{M}^{-1} \cdot \mathrm{sec}^{-1}$ and intercept of $0.072 \mathrm{sec}^{-1}$. $D$, Reciprocal of recovery time constant versus toxin concentration. Line is drawn at the mean value. Solutions as in Figure $1 A(10 \mu \mathrm{M}$ nimodipine in all external solutions).

exponential (Fig. $4 A$ ), and the rate constant of block derived from such fits was related linearly to toxin concentration, consistent with $1: 1$ binding of toxin to channels. The relationship gives a binding rate constant of $1.5 \times 10^{3} \mathrm{M}^{-1} \cdot \mathrm{sec}^{-1}$, which is $\sim 700$ times slower than in sympathetic neurons. The off-rate was estimated by analyzing the rate of recovery after the rapid block by a short application of $30 \mu \mathrm{M} \omega$-CTx-MVIIC (Fig. $4 C$ ). The rate of recovery was estimated assuming exponential recovery during the first $10 \mathrm{~min}$, when run-down of the current would be expected to be minimal; this fit yielded an estimated time constant of $200 \mathrm{~min}$. (At later times, the actual degree of recovery was much less than predicted from this fit, very likely because of concurrent run-down of channel activity.) The estimated off-rate is subject to considerable uncertainty, but time constants shorter or longer by more than a factor of 2 gave poor fits to the first $10 \mathrm{~min}$ of recovery. The dissociation constant calculated from the ratio of the off-rate and on-rate constant is $\sim 50 \mathrm{nM}$. Apparently, $\omega$-CTX-MVIIC block of P-type current is potent but very slow.


Figure 4. Blocking kinetics in Purkinje neurons with $5 \mathrm{mM} \mathrm{Ba}^{2+} . A$, Block in three different Purkinje neurons by $2 \mu \mathrm{M}, 10 \mu \mathrm{M}$, and $30 \mu \mathrm{M} \omega$-CTxMVIIC. Solid lines are single exponentials with the indicated time constants. $B$, Points are mean \pm SEM for determinations in four cells at each concentration. Line has slope $1.5 \times 10^{3} \mathrm{M}^{-1} \cdot \mathrm{sec}^{-1}$ and intercept $6 \times$ $10^{-4} \cdot \mathrm{sec}^{-1} . C$, Time course of recovery for Purkinje neuron studied with $5 \mathrm{~mm} \mathrm{Ba}^{2+}$. Current was elicited every $5 \mathrm{sec}$ (every $30 \mathrm{sec}$ during wash) by $20 \mathrm{msec}$ steps from $-80 \mathrm{mV}$ to $-25 \mathrm{mV} ; 30 \mu \mathrm{M} \omega$-CTx-MVIIC was applied for $220 \mathrm{sec}$. Solid line is an exponential fit to the recovery in the first $10 \mathrm{~min}$ of washing, assuming eventual recovery to $1500 \mathrm{pA}$. Solutions as in Figure $1 B(10 \mu \mathrm{M}$ nimodipine, $1 \mu \mathrm{M} \omega$-conotoxin GVIA in all external solutions).

\section{Dependence on $\mathrm{Ba}^{2+}$ and ionic strength}

The potency and kinetics of block by $\omega$-CTx-MVIC applied to sympathetic neurons depended strongly on the concentration of $\mathrm{BaCl}_{2}$ in the external solution. Figure 5 shows the contrast in effects of $\omega$-CTX-MVIIC studied in different concentrations of $\mathrm{BaCl}_{2}$ (added to a background of 145 or $160 \mathrm{TEACl}, 10 \mathrm{~mm}$ HEPES, $\mathrm{pH} 7.4$, adjusted with TEAOH). The half-maximal concentration increased from $3 \mathrm{nM}$ with $2 \mathrm{mM} \mathrm{BaCl}_{2}$ to $850 \mathrm{~nm}$ with $25 \mathrm{mM} \mathrm{BaCl}_{2}$. With the higher concentrations of $\mathrm{BaCl}_{2}$, there was a greater fraction of current that remained unblocked by maximal concentrations of $\omega$-CTX-MVIIC (and $10 \mu \mathrm{M}$ nimodipine). This behavior is also seen with block by the combination of 

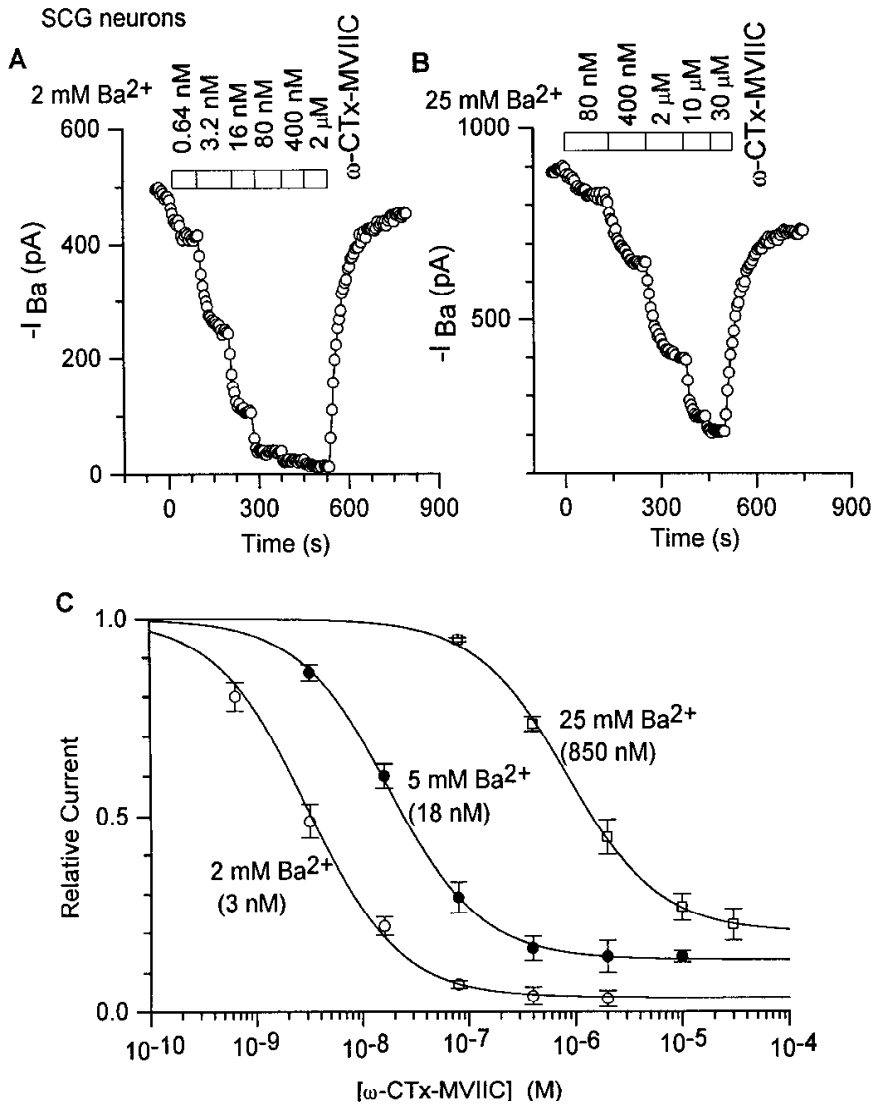

Figure 5. Effect of $\mathrm{Ba}^{2+}$ concentration on $\omega$-CTx-MVIIC dose-response relationship in SCG neurons. $A$, Time course of block by increasing concentrations of $\omega$-CTx-MVIIC in a rat SCG neuron studied with $2 \mathrm{~mm}$ $\mathrm{Ba}^{2+}$. Current was elicited every $5 \mathrm{sec}$ by a $30 \mathrm{msec}$ step from $-90 \mathrm{mV}$ to $-10 \mathrm{mV}$. Solutions as in Figure $1 A$ except that the external solution contained $2 \mathrm{mM} \mathrm{BaCl}_{2}$ instead of $5 \mathrm{mM} \mathrm{BaCl}_{2}(10 \mu \mathrm{M}$ nimodipine in all external solutions). $B$, The same for block in a different neuron studied with $25 \mathrm{mM} \mathrm{Ba}^{2+}$. The external solution contained $25 \mathrm{mM} \mathrm{BaCl}_{2}$ instead of $5 \mathrm{mM} \mathrm{BaCl}_{2}$ and $145 \mathrm{~mm}$ TEACl instead of $160 \mathrm{~mm}$ TEACl $(10 \mu \mathrm{M}$ nimodipine in all external solutions). Current was elicitcd cvery 5 scc by a $30 \mathrm{msec}$ step from $-80 \mathrm{mV}$ to $0 \mathrm{mV}$. $C$, Mean dose-response relationships. Points are mean \pm SEM for determinations in three cells for $2 \mathrm{mM}$ $\mathrm{Ba}^{2+}(2$ cells for $80 \mathrm{nM})$ and two cells for $25 \mathrm{mM} \mathrm{Ba}^{2+}$ ( 4 cells for $400 \mathrm{nM}$ ). Data for $5 \mathrm{mM} \mathrm{Ba}^{2+}$ are same as in Figure $2 B$. Solid lines are best fits to the expression $(1-x)+x /\left(1+[\omega-C\right.$ Tx-MVIIC $\left.] / E_{50}\right)$, where $x$ is the maximal fraction of current blocked by $\omega$-CTx-MVIIC $(0.96$ for $2 \mathrm{~mm}$ $\mathrm{Ba}^{2+}, 0.87$ for $5 \mathrm{mM} \mathrm{Ba}^{2+}$, and 0.79 for $25 \mathrm{mM} \mathrm{Ba}^{2+}$ ), and $\mathrm{EC}_{50}$ is the half-maximally effective dose of $\omega$-CTx-MVIIC ( $3 \mathrm{nM}$ for $2 \mathrm{mM} \mathrm{Ba}^{2+}, 18$ $\mathrm{nM}$ for $5 \mathrm{mM} \mathrm{Ba}^{2+}$, and $850 \mathrm{nM}$ for $25 \mathrm{mM} \mathrm{Ba}^{2+}$ ).

$\omega$-conotoxin GVIA and nimodipine in rat and frog sympathetic neurons, where the remaining current has been interpreted as a third channel type (Boland et al., 1994; Elmslie et al., 1994). The simplest interpretation is that the current remaining unblocked by saturating $\omega$-CTX-MVIIC results from this third channel type; however, it is not possible to rule out the possibility that block of $\mathrm{N}$-type channels becomes incomplete at high $\mathrm{BaCl}_{2}$ concentrations.

Figure 6 shows a kinetic analysis of the effects of $\mathrm{Ba}^{2+}$ concentration on the potency of $\omega$-CTX-MVIIC block in sympathetic neurons. In both $2 \mathrm{mM} \mathrm{Ba}^{2+}$ and $25 \mathrm{mM} \mathrm{Ba}^{2+}$, the kinetics of block followed the form expected for simple 1:1 binding. The ability of both on and off time courses to be fit well by a single exponential suggests that a single population of channels underlies the effects at each $\mathrm{Ba}^{2+}$ concentration, consistent with the
SCG neurons
A $2 \mathrm{mM} \mathrm{Ba}^{2+}$

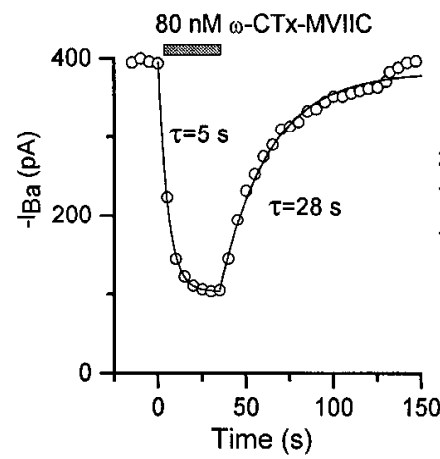

C

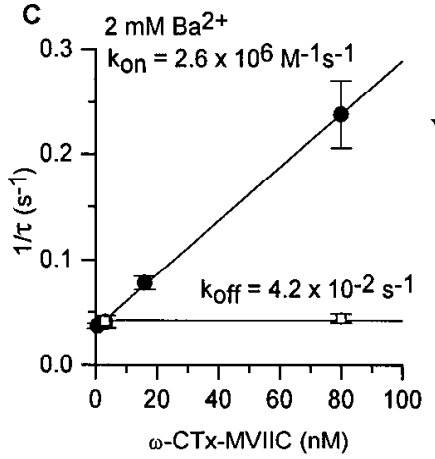

B $25 \mathrm{mM} \mathrm{Ba}^{2+}$

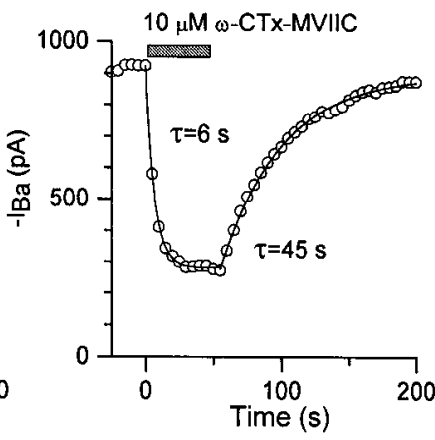

D



Figure 6. Effect of $\mathrm{BaCl}_{2}$ concentration on kinetics of block and recovery in SCG neurons. $A$, Block by $80 \mathrm{nM} \omega$-CTx-MVIIC in a neuron studied with $2 \mathrm{mM} \mathrm{BaCl}_{2}$. Current was elicited every $5 \mathrm{sec}$ by a $30 \mathrm{msec}$ step from $-80 \mathrm{mV}$ to $-20 \mathrm{mV}$. $B$, Block by $10 \mu \mathrm{M} \omega$-CTx-MVIIC in a different neuron studied with $25 \mathrm{mM} \mathrm{BaCl}$. Current was elicited every $5 \mathrm{sec}$ by a 30 msec step from $-80 \mathrm{mV}$ to $0 \mathrm{mV}$. $C$, Mean $( \pm$ SEM) time constants for block (closed circles) and recovery (open squares) in experiments with $2 \mathrm{mM}$ $\mathrm{BaCl}_{2}$. On-rate determined for four cells at $0.64 \mathrm{~nm}$, eight cells at $3.2 \mathrm{nM}$, five cells at $16 \mathrm{nM}$, and six cells at $80 \mathrm{nM}$. Line fitted to on-rates has slope $2.6 \times 10^{6} \mathrm{M}^{-1} \cdot \mathrm{sec}^{-1}$ and intercept $0.035 \mathrm{sec}^{-1}$. Off-rate determined for five cells at $3.2 \mathrm{nM}$ and three cells at $80 \mathrm{nM}$. Line through off-rates is average of values for these 8 cells $\left(0.042 \pm 0.003 \mathrm{sec}^{-1}\right)$. $D$, Mean $( \pm$ SEM) reciprocal time constants for block (closed circles) and recovery (open squares) in experiments with $25 \mathrm{mM} \mathrm{BaCl}_{2}$. On-rate determined for five cells with $400 \mathrm{nM}$, three cells for $2 \mu \mathrm{M}$, two cells for $10 \mu \mathrm{M}$, and two cells for $30 \mu \mathrm{M}$. Line fitted to on-rates has slope $1.4 \times 10^{-4} \mathrm{M}^{-1} \cdot \mathrm{sec}^{-1}$ and intercept $0.026 \mathrm{sec}^{-1}$. Off-rate determined for two cells at each concentration except $10 \mu \mathrm{M}$ ( 3 cells). Line through off-rates is average of values for these nine cells $\left(0.027 \pm 0.006 \mathrm{sec}^{-1}\right)$.

"resistant" current (which is more prominent at higher $\mathrm{Ba}^{2+}$ ) being insensitive to $\omega$-CTx-MVIIC. The rate constant for toxin binding decreased by a factor of $\sim 200$ when $\mathrm{Ba}^{2+}$ was increased from $2 \mathrm{mM}$ to $25 \mathrm{mM}$; thus, the change in $\mathrm{EC}_{50}$ ( $\sim 300$-fold) is mostly accounted for by a change in the association rate constant. There was also a slight influence of $\mathrm{Ba}^{2+}$ concentration on the off-rate constant, which decreased from $0.042 \mathrm{sec}^{-1}$ with $2 \mathrm{mM}$ $\mathrm{Ba}^{2+}$ to $0.027 \mathrm{sec}^{-1}$ with $25 \mathrm{mM} \mathrm{Ba}{ }^{2+}$. At all concentrations of $\mathrm{Ba}^{2+}$, the $K_{\mathrm{d}}$ calculated from the ratio of the dissociation and association rate constants was considerably larger than the $\mathrm{EC}_{50}$ measured from the dose-response relationship (Table 1).

The powerful dependence of $k_{\text {on }}$ but not $k_{\text {off }}$ on $\mathrm{Ba}^{2+}$ concentration is consistent qualitatively with a surface-charge screening mechanism. The toxin has a predicted net positive charge of +7 at neutral $\mathrm{pH}$ (four lysines, three arginines, one aspartate, amidated $\mathrm{C}$ terminus). If the binding site for the toxin is near negative charges (from the channel protein, phospholipid head groups, or 


\begin{tabular}{|c|c|c|c|c|}
\hline Ionic conditions & $k_{\mathrm{on}}\left(\mathrm{M}^{-1} \cdot \sec ^{-1}\right)$ & $k_{\mathrm{off}}\left(\mathrm{sec}^{-1}\right)$ & $K_{\mathrm{d}}=\left(k_{\mathrm{off}} / k_{\mathrm{on}}\right)$ & $\mathrm{EC}_{50}$ \\
\hline \multicolumn{5}{|l|}{ N-type channels (SCG neurons) } \\
\hline $5 \mathrm{mM} \mathrm{Ba}^{2+}$ & $1.1 \times 10^{6}$ & $3.2 \times 10^{-2}$ & $30 \mathrm{~nm}$ & $18 \mathrm{nM}$ \\
\hline $25 \mathrm{mM} \mathrm{Ba}^{2+}$ & $1.4 \times 10^{4}$ & $2.7 \times 10^{-2}$ & $1930 \mathrm{nM}$ & $850 \mathrm{nM}$ \\
\hline $2 \mathrm{mM} \mathrm{Ba}^{2+}$, low ionic strength & $7.2 \times 10^{6}$ & $2.8 \times 10^{-2}$ & $4 \mathrm{~nm}$ & \\
\hline \multicolumn{5}{|l|}{ P-type channels (Purkinje neurons) } \\
\hline $2 \mathrm{mM} \mathrm{Ba}^{2+}$ & $1.3 \times 10^{4}$ & & $(\sim 5 \mathrm{nM})^{a}$ & \\
\hline $5 \mathrm{mM} \mathrm{Ba}^{2+}$ & $1.5 \times 10^{3}$ & $\sim 8 \times 10^{-5}$ & $\sim 50 \mathrm{nM}$ & \\
\hline $2 \mathrm{mM} \mathrm{Ba}^{2+}$, low ionic strength & $1.5 \times 10^{5}$ & & $(\sim 0.5 \mathrm{nM})^{a}$ & \\
\hline $2 \mathrm{mM} \mathrm{Ca}^{2+}, 2 \mathrm{mM} \mathrm{Mg}^{2+}$ & $8.5 \times 10^{2}$ & & & \\
\hline
\end{tabular}



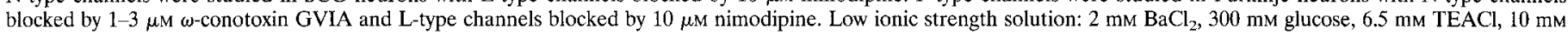
IIEPES, pII 7.4 with TEAOII.

${ }^{a}$ Values estimated using off-rate with $5 \mathrm{~mm} \mathrm{Ba}^{2+}$.

glycosyl groups), the local toxin concentration would be significantly higher than that in bulk solution. Increasing concentrations of $\mathrm{Ba}^{2+}$ would partially screen the surface charge and reduce the local concentration of the toxin, resulting in a reduction in the apparent binding rate. If the effect of $\mathrm{Ba}^{2+}$ concentration is mediated by a surface-charge effect, there should also be effects on blocking rate when $\mathrm{Ba}^{2+}$ concentration is held constant and changes are made in the ionic strength of the solution by changing monovalent ions. This was tested and confirmed. When studied with $3.2 \mathrm{nM}$ toxin, the time constant for block was smaller $(\tau=$ $3.8 \pm 0.5 \mathrm{sec}, n=4)$ in a solution of low ionic strength $(2 \mathrm{mM}$ $\mathrm{BaCl}_{2}, 300 \mathrm{~mm}$ glucose, $6.5 \mathrm{~mm}$ TEACl, $10 \mathrm{~mm}$ HEPES, pH 7.4, adjusted with TEAOH) than that $(\tau=20 \pm 6 \mathrm{sec}, n=4)$ in a solution with normal ionic strength $\left(2 \mathrm{mM} \mathrm{BaCl}_{2}, 160 \mathrm{~mm} \mathrm{TEACl}\right.$, $10 \mathrm{~mm}$ HEPES, pH 7.4, adjusted with TEAOH). Similarly, when studied with $80 \mathrm{~nm}$ toxin, block was slower $(\tau=16 \pm 3 \mathrm{sec}, n=$ 3 ) in a solution with high ionic strength $\left(2 \mathrm{mM} \mathrm{BaCl}_{2}, 160 \mathrm{~mm}\right.$ TEACl, $100 \mathrm{~mm} \mathrm{CsCl}, 10 \mathrm{~mm}$ HEPES, $\mathrm{pH} 7.4$, adjusted with TEAOH) than block $(\tau=5.2 \pm 0.3 \mathrm{sec}, n=4)$ in a solution with normal ionic strength $\left(2 \mathrm{mM} \mathrm{BaCl}_{2}, 100 \mathrm{~mm}\right.$ glucose, $160 \mathrm{~mm}$ TEACl, $10 \mathrm{~mm}$ HEPES, $\mathrm{pH} 7.4$, adjusted with TEAOH). The recovery from block showed smaller differences between low ionic strength solution ( $\tau=36 \pm 3 \mathrm{sec}, n=4$ ), normal ionic strength solution $(\tau=25 \pm 2 \mathrm{sec}, n=8)$, and high ionic strength solution $(\tau=17 \pm 1 \mathrm{sec}, n=3)$.

The block of current by $\omega$-CTx-MVIIC applied to Purkinje cells was even more strongly influenced by the $\mathrm{Ba}^{2+}$ concentration (Fig. 7). The development of block with $2 \mathrm{mM} \mathrm{Ba}^{2+}$ developed with a time constant of $1.3 \times 10^{4} \mathrm{M}^{-1} \cdot \mathrm{sec}^{-1}$, ninefold faster than with $5 \mathrm{mM} \mathrm{Ba}^{2+}$. This change is greater than that seen for sympathetic neurons, where the blocking rate constant changed approximately fourfold from $2 \mathrm{~mm}$ to $5 \mathrm{~mm} \mathrm{Ba}^{2+}$. This suggests that surface-charge effects may be greater for P-type than for $\mathrm{N}$-type channels. Consistent with this, changing ionic strength by monovalents had greater effects in Purkinje neurons than in sympathetic neurons. When studied with $400 \mathrm{~nm}$ toxin, the blocking time constant changed from $169 \pm 27 \mathrm{sec}$ in a solution of normal ionic strength to $17 \pm 1 \mathrm{sec}$ with the low ionic strength. solution (in which the solutions were the same as those used for studying sympathetic neurons). This 10 -fold change is more than the fivefold change seen for the same solutions in sympathetic neurons. Similarly, the blocking time constant for $10 \mu \mathrm{M}$ toxin

\section{Purkinje neurons}

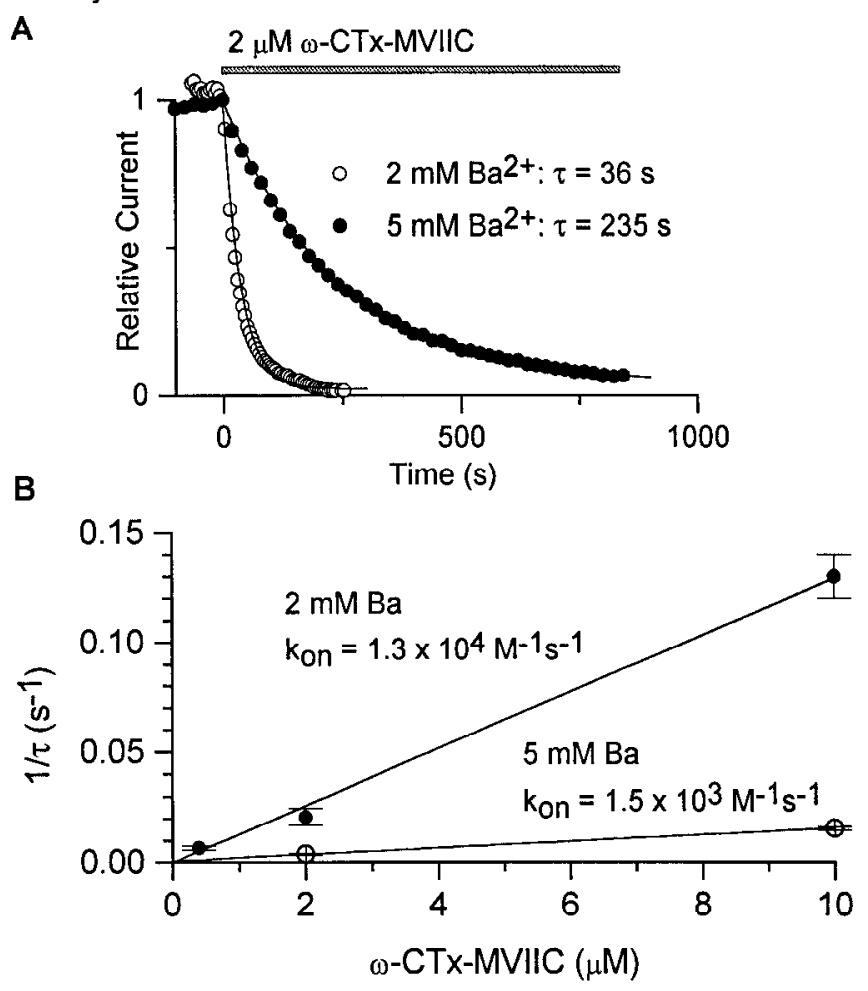

Figure 7. Effect of $\mathrm{BaCl}_{2}$ concentration on kinetics of block in Purkinje neurons. $A$, Time course of block by $2 \mu \mathrm{M} \omega$-CTx-MVIIC in two Purkinje neurons studied with $2 \mathrm{mM} \mathrm{BaCl}_{2}$ and $5 \mathrm{mM} \mathrm{BaCl}_{2}$. Currents in $2 \mathrm{~mm}$ $\mathrm{BaCl}_{2}$ solution elicited by $30 \mathrm{msec}$ steps from -80 to $-30 \mathrm{mV}$ delivered every $5 \mathrm{sec}$; currents in $5 \mathrm{mM} \mathrm{BaCl}_{2}$ solution elicited by $30 \mathrm{msec}$ steps from -80 to $-20 \mathrm{mV}$ delivered every $20 \mathrm{sec} . B$, Mean ( \pm SEM) reciprocal time constants for block in experiments with $2 \mathrm{mM} \mathrm{BaCl}_{2}(\bullet)$ and $5 \mathrm{mM} \mathrm{BaCl}_{2}$ (O). In experiments with $2 \mathrm{mM} \mathrm{BaCl}_{2}$, the on-rate was determined for five cells with $400 \mathrm{nM}$, three cells for $2 \mu \mathrm{M}$, and five cells for $10 \mu \mathrm{M}$. The solid line has slope $1.3 \times 10^{-4} \mathrm{M}^{-1} \cdot \mathrm{sec}^{-1}$ and intercept 0 . The data and fitted line for $5 \mathrm{~mm} \mathrm{BaCl} 2$ are replotted from Figure 4 (10 $\mu \mathrm{M}$ ninodipine, $1 \mu \mathrm{m}$ $\omega$-conotoxin GVIA in all external solutions).

increased from $7.7 \pm 0.7 \mathrm{sec}$ in normal ionic strength solution to $43 \pm 5 \mathrm{sec}$ with high ionic strength solution. This 5.5 -fold change is more than the threefold change seen for the same solutions with sympathetic neurons. 
The changes in kinetics with ionic strength are consistent with a mechanism whereby the effective toxin concentration is altered because of screening of surface charge. Preliminary calculations suggest that when ionic strength is changed by monovalents, the effects on block of $\mathrm{N}$-type channels can be accounted for by a surface charge of $0.009 \mathrm{e} / \AA^{2}$ and an effective charge of $\omega$-CTxMVIIC of +4 (for method of calculation, see Boland et al., 1994). A surface charge of $\sim 0.01 \mathrm{e} / \AA^{2}$ is similar to estimates based on shifts of gating of calcium channels in other neurons (Kostyuk et al., 1982; Wilson et al., 1983; Zhou and Jones, 1995). The experimental effects of changing $\mathrm{BaCl}_{2}$ were greater than predicted from a simple Gouy-Chapman model with these values. This implies that $\mathrm{Ba}^{21}$ may bind to specific sites rather than merely interact with smeared surface charge. Toxin molecules possibly compcte with $\mathrm{Ba}^{2+}$ for binding at the outer mouth of the pore, where there is high-affinity binding of divalent ions that underlies the selectivity of the calcium channel (Kuo and Hess, 1993; Ellinor et al., 1995). Clearly, the effects of changing $\mathrm{Ba}^{2+}$ are not attributable solely to a competitive mechanism, because a fivefold change in $\mathrm{Ba}^{2+}$, from $5 \mathrm{~mm}$ to $25 \mathrm{~mm}$, produces a 64-fold change in apparent affinity for $\mathrm{N}$-type channels (Table 1 ); similarly, the >eightfold slowing in the rate of block of $\mathrm{P}$-type channels produced by raising $\mathrm{Ba}^{2+}$ from 2 to $5 \mathrm{~mm}$ is much more than the 2.5-fold expected from a simple competition. Also, the effects of ionic strength varied by monovalent ions show that more is involved than simple competition between toxin and divalent ions. It is possible that both simple surface charge screening and competition at the pore mouth (or other sites) contribute to the effects of changing $\mathrm{Ba}^{21}$ concentration.

\section{w-CTx-MVIIC block of calcium channel current in hippocampal neurons}

Hippocampal CA3 neurons possess multiple components of highthreshold calcium channel current, including components sensitive to dihydropyridines, $\omega$-conotoxin GVIA, and $\omega$-Aga-IVA, as well as a component resistant to all of these (Mintz et al., 1993). Figure 8 shows the response of a hippocampal CA3 neuron to 10 $\mu \mathrm{M} \omega$-CTx-MVIIC. Of the total high-threshold current of $360 \mathrm{pA}$ in this neuron (measured at $-20 \mathrm{mV}$ ), $\omega$-CTX-MVIIC inhibited $165 \mathrm{pA}$. The toxin-sensitive current consisted of two components blocked with very different kinetics (Fig. $8 A$ ): a component of 60 pA was blocked within $5 \mathrm{sec}$ and a component of $105 \mathrm{pA}$ was blocked with a much slower time course, fit with a single exponential of $86 \mathrm{sec}$. On washout of the toxin, $\sim 60 \mathrm{pA}$ of current returned within $1 \mathrm{~min}$, and this component of current could then be blocked reversibly with subsequent applications and washout of toxin. In contrast, the component of current blocked with slow kinetics behaved as if block was essentially irreversible on the time scale of the experiment. In four cells studied with this protocol, the fast, reversible component of block averaged $22 \pm 2 \%$ of the overall current, whereas the slow, poorly reversible component averaged $30 \pm 3 \%$ of the overall current. The average time constant for the slow block was $89 \pm 2$ sec.

The fast, reversible component of block behaves kinetically as expected if it corresponds to N-type current, as characterized in sympathetic neurons. In a previous series of experiments on CA3 neurons studied with $5 \mathrm{mM} \mathrm{Ba}^{2+}$ (Mintz et al., 1992a), $\omega$-conotoxin GVIA blocked an average of $21 \pm 2 \%$ of the overall current, in close agreement with the size of the fast, reversible component observed with $\omega$-CTx-MVIIC $(22 \pm 2 \%)$. Consistent with this interpretation, $\omega$-CTX-MVIIC blocked with only a slow time course if applied after a cell was exposed to $\omega$-conotoxin GVIA.

\section{CA3 neuron}

$5 \mathrm{mM} \mathrm{Ba}^{2+}$
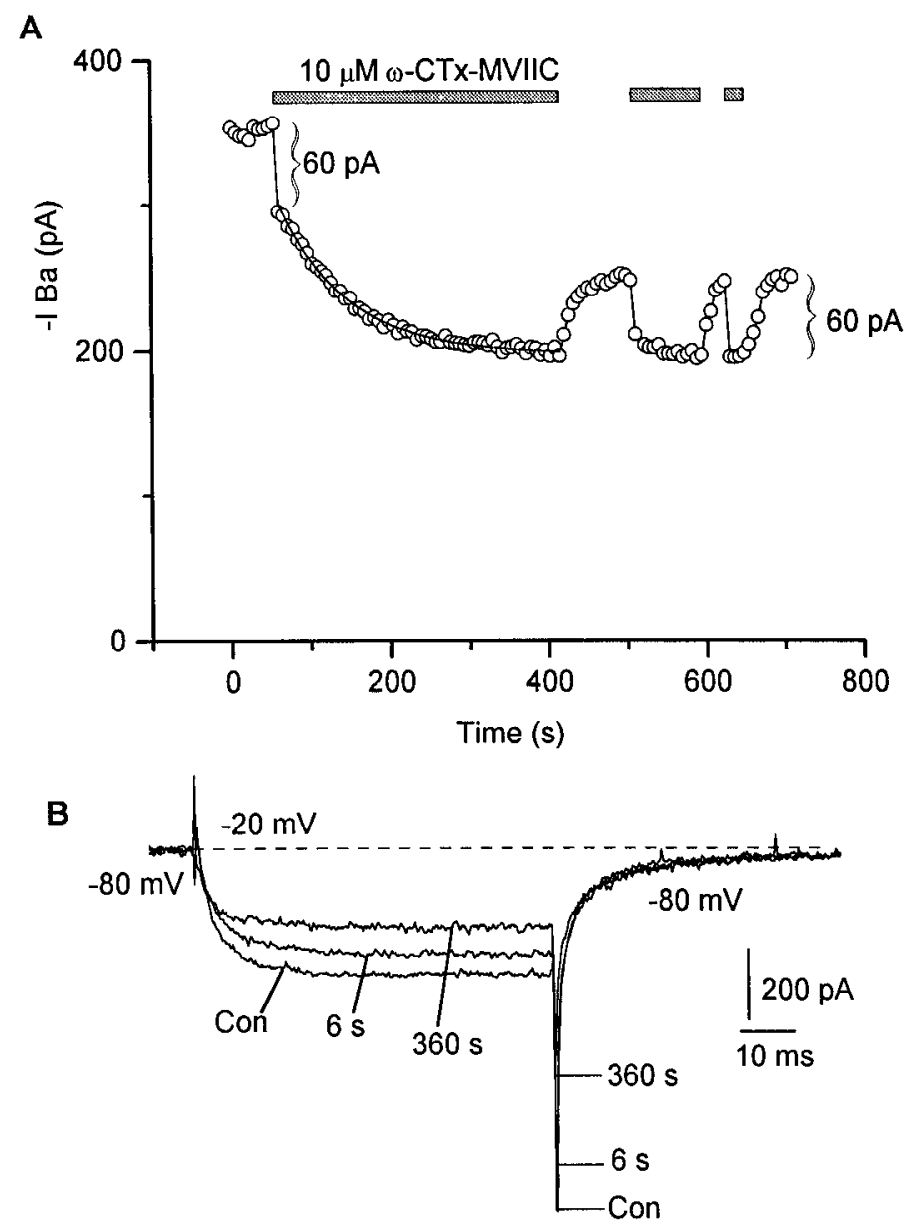

Figure 8. Dual component time course of block by $10 \mu \mathrm{M} \omega$-C Tx-MVIIC of overall calcium channel current in a hippocampal CA3 neuron studied with $5 \mathrm{mM} \mathrm{Ba}^{2+}$. $A$, Time course of block. Current was elicited by steps from $-80 \mathrm{mV}$ to $-20 \mathrm{mV}$ delivered every $6 \mathrm{sec}$. The bracket indicates magnitude of current $(60 \mathrm{pA})$ blocked in the first $6 \mathrm{sec}$ of the first application of $\omega$-CTx-MVIIC. The slow time course after the initial fast component is fit with a time constant of $86 \mathrm{sec}$ (not distinguishable from data points). $B, \mathrm{Ba}^{2+}$ currents from the experiment in $A$ recorded just before, $6 \mathrm{sec}$ after, and $360 \mathrm{sec}$ after application of $\omega$ CTx MVIIC. The slow component of tail current at $-80 \mathrm{mV}$ is consistently present in hippocampal CA3 neurons. $\omega$-CTx-MVIIC had no effect on this slow tail, consistent with it being L-type current (Swartz and Bean, 1992). Instead, both the fast and slow effects of $\omega$-CTx-MVIIC involved block of rapidly decaying portions of the tail current. External solution: $5 \mathrm{~mm} \mathrm{BaCl}, 160$ $\mathrm{mM}$ 'TEACI, $10 \mathrm{~mm}$ HEPES, pH 7.4, adjusted with TEAOH, $1 \mathrm{mg} / \mathrm{ml}$ cytochrome C, $1 \mu \mathrm{M}$ tetrodotoxin (no nimodipine or $\omega$-conotoxin GVIA). Dashed line indicates zero current level.

The component of current in hippocampal neurons blocked by $\omega$-CTX-MVIIC with slow kinetics most likely includes $\omega$-Aga-IVA-sensitive channels, because these are blocked in Purkinje neurons with similarly slow $(\tau=65 \pm 4 \mathrm{sec}$ with $10 \mu \mathrm{M}$ $\omega$-CTx-MVIIC), poorly reversible kinetics. To check for additional components of $\omega$-CTX-MVIIC-sensitive current, we tested the toxin after exposing CA3 neurons to $\omega$-Aga-IVA. Figure $9 A$ shows the application of $\omega$-CTx-MVIIC to a hippocampal neuron exposed previously to nimodipine $(10 \mu \mathrm{M})$, $\omega$-conotoxin GVIA ( $3 \mu \mathrm{M})$, and $200 \mathrm{~nm} \omega$-Aga-IVA. After the application of these blockers (and in their continued presence), $10 \mu \mathrm{M} \omega$-CTx-MVIIC blocked $\sim 40 \%$ of the remaining current 

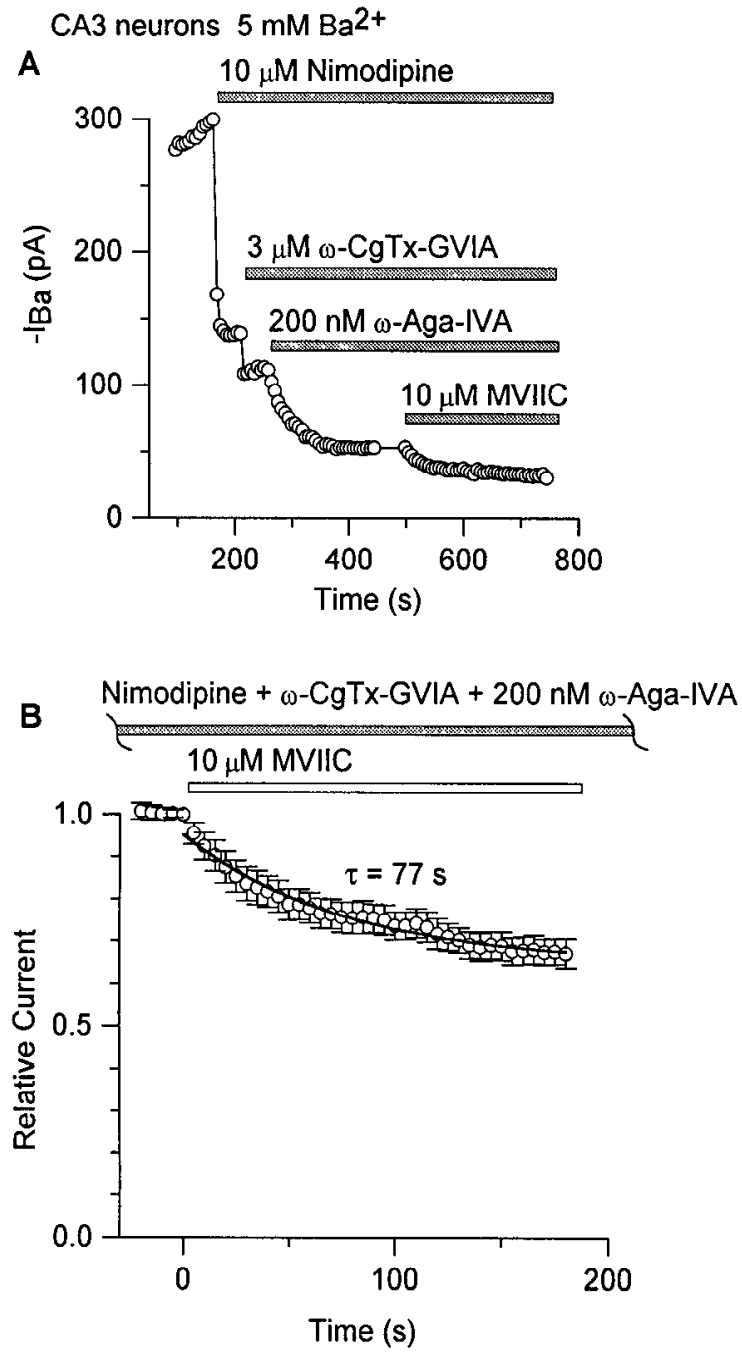

Figure 9. Time course of block by $\omega$-CTX-MVIIC of hippocampal current resistant to nimodipine, $\omega$-conotoxin-GVIA, and $200 \mathrm{nM} \omega$-Aga-IVA. $A$, Cumulative application of $10 \mu \mathrm{M}$ nimodipine, $3 \mu \mathrm{M} \omega$-conotoxin-GVIA, $200 \mathrm{nM} \omega$-Aga-IVA, and $10 \mu \mathrm{M} \omega$-CTx-MVIIC to a hippocampal CA3 neuron. Current was elicitcd cvery $6 \mathrm{sec}$ by a $20 \mathrm{msec}$ pulse from -80 to $-20 \mathrm{mV}$. Corrected for leak current after application of $300 \mu \mathrm{M} \mathrm{Cd^{2+ }} . B$, Average time course of block by $10 \mu \mathrm{M} \omega$-CTx-MVIIC in the presence of nimodipine, $\omega$-conotoxin-GVIA, and $200 \mathrm{nM} \omega$-Aga-IVA in CA3 neurons. Time course records from nine neurons were averaged (mean \pm SEM), with current normalized to that in the presence of the three other blockers (which was $23 \pm 3 \%$ of the initial control current) before application of $\omega$-CTx-MVIIC. In four neurons, $10 \mu \mathrm{M}$ nimodipine, $3 \mu \mathrm{M} \omega$-conotoxinGVIA, $200 \mathrm{nM} \omega$-Aga-IVA, and $10 \mu \mathrm{M} \omega$-CTx-MVIIC were applied, and test pulse current was elicited every $5 \mathrm{sec}$. In the other five neurons, $5 \mu \mathrm{M}$ nimodipine, $1 \mu \mathrm{M} \omega$-conotoxin-GVIA, $200 \mathrm{nM} \omega$-Aga-IVA, and $10 \mu \mathrm{M}$ $\omega$-CTx-MVIIC were applied, and test pulse current was elicited every 6 $\mathrm{sec}$; current values were interpolated at $5 \mathrm{sec}$ intervals to allow averaging with the other series. The averaged time course was fit well by a single cxponcntial with a time constant of $77 \mathrm{scc}$ (solid line).

( $7 \%$ of the overall current). The action of $\omega$-CTx-MVIIC was slow, with a time constant of $45 \mathrm{sec}$.

a-CTx-MVIIC $(10 \mu \mathrm{M})$ clearly blocked additional current in 10 of 12 hippocampal neurons in which it was added after 5-10 $\mu \mathrm{M}$ nimodipine, $1-2 \mu \mathrm{M} \omega$-conotoxin GVIA, and $200 \mathrm{nM} \omega$-Aga-IVA. In these 12 cells, the combination of the three other blockers blocked an average of $77 \pm 3 \%$ of the initial control current, $\omega$-CTX-MVIIC blocked an additional $8 \pm 1 \%$, and $15 \pm 3 \%$ remained unblocked $(n=12)$. In a subset of nine neurons, the effects of each of the other three blockers was determined individually (rather than applying all three simultaneously). In these nine neurons, $200 \mathrm{~nm} \omega$-Aga-IVA inhibited $18 \pm 3 \%$ of the overall current, and $\omega$-CTX-MVIIC blocked an additional $8 \pm 1 \%$. Thus, the average fraction of current blocked slowly by $\omega$-CTx-MVIIC applied alone $(30 \pm 3 \%)$ is reasonably close to the sum $(26 \pm 3 \%)$ of the fraction sensitive only to $\omega$-CTX-MVIIC and the fraction sensitive to $200 \mathrm{~nm} \omega$-Aga-IVA. This is consistent with $\omega$-CTxMVIIC blocking both $\omega$-Aga-IVA-sensitive and -insensitive components as part of the overall slowly blocked component.

Figure $9 B$ shows the average time course of block for nine neurons (including two in which toxin had little or no effect) in which $\omega$-CTX-MVIIC was applied for at least $3 \mathrm{~min}$ in the presence of 5-10 $\mu \mathrm{M}$ nimodipine, 1-2 $\mu \mathrm{M} \omega$-conotoxin GVIA, and 200 nM $\omega$-Aga-IVA. Block devclopcd slowly, with a time constant (fit to the averaged data) of $77 \mathrm{sec}$. This suggests that $\omega$-CTX-MVIIC blocks the $\omega$-Aga-IVA-insensitive component with slow kinetics, similar to the slow block of P-type channels in Purkinje neurons.

Recently, Randall and Tsien (1995) reported the existence in cerebellar granule neurons of a component of current, named "Q-type" current, that is blocked by $\omega$-Aga-IVA with relatively low affinity $\left(K_{\mathrm{d}} \sim 90 \mathrm{~nm}\right)$ and is also blocked by $\omega$-CTX-MVIIC. Such a current in CA3 neurons could constitute the component blocked by $\omega$-CTx-MVIIC in the presence of $200 \mathrm{~nm} \omega$-Aga-IVA. If so, it should be blocked by higher concentrations of $\omega$-AgaIVA. We therefore tested the effects of $1 \mu \mathrm{M} \omega$-Aga-IVA after achieving steady-state block by $10 \mu \mathrm{M}$ nimodipine, $3 \mu \mathrm{M}$ $\omega$-conotoxin GVIA, and $200 \mathrm{~nm} \omega$-Aga-IVA (applied for at least $3 \mathrm{~min}$ ). In three of five CA3 neurons tested, $1 \mu \mathrm{M} \omega$-Aga-IVA produced detectable additional block. Although these experiments confirm the existence of current components blocked weakly by $\omega$-Aga-IVA, the effects of $1 \mu \mathrm{M} \omega$-Aga-IVA in the five cells tested were highly variable and poorly correlated with the effects of $200 \mathrm{nM} \omega$-Aga-IVA, which had no effect in one neuron in which subsequent addition of $1 \mu \mathrm{M} \omega$-Aga-IVA produced inhibition. In previous experiments testing 100-200 nM $\omega$-Aga-IVA on various types of central neurons, CA3 neurons showed the greatest variability and least sensitivity $(14 \pm 3 \%$ mean block; Mintz et al., 1992a). Rather than attempting a further understanding of the inconsistent effects of $\omega$-Aga-IVA on CA3 neurons, we turned instead to the question of whether $1 \mu \mathrm{M} \omega$-Aga-IVA would (in combination with nimodipine and $\omega$-conotoxin GVIA) occlude the effects of $\omega$-CTx-MVIIC. When a combination of $10 \mu \mathrm{M}$ nimodipine, $3 \mu \mathrm{M} \omega$-conotoxin GVIA, and $1 \mu \mathrm{M} \omega$-Aga-IVA was applied (for a minimum of $2 \mathrm{~min}$, long enough to reach steady state), $10 \mu \mathrm{M} \omega$-CTx-MVIIC still produced additional block in six of eight $\mathrm{C} \Lambda 3$ neurons tested. Figure 10 shows a representative cell in which $10 \mu \mathrm{M}$ nimodipine, $3 \mu \mathrm{M} \omega$-conotoxin GVIA, and $1 \mu \mathrm{M}$ $\omega$-Aga-IVA blocked $69 \%$ of the current, and $\omega$-CTx-MVIIC blocked an additional $8 \%$. In this series of experiments, the three-blocker mixture inhibited an average of $78 \pm 2 \%$ of the initial control current, $\omega$-CTx-MVIIC blocked an additional $7 \pm$ $1 \%$, and $16 \pm 2 \%$ remained unblocked $(n=8)$. These are similar to the values obtained with $200 \mathrm{~nm} \omega$-Aga-IVA, which is somewhat surprising in view of the ability of $1 \mu \mathrm{M} \omega$-Aga-IVA to block current beyond that blocked by $200 \mathrm{~nm} \omega$-Aga-IVA in some cells; however, the two sets of experiments were performed using separate batches of cells, between which there is undoubtedly more systematic variability than is reflected by standard errors. The time course of further block by $\omega$-CTX-MVIIC added to nimodipine, $\omega$-conotoxin GVIA, and $1 \mu \mathrm{M} \omega$-Aga-IVA occurred with an average time constant of $38 \pm 9 \mathrm{sec}$ for the four cells in which it 




Figure 10. Block by $\omega$-CTx-MVIIC of current resistant to nimodipine, $\omega$-conotoxin-GVIA, and $1 \mu \mathrm{M} \omega$-Aga-IVA in a CA3 neuron. Current was elicited every $6 \mathrm{sec}$ by a $20 \mathrm{msec}$ pulse from -80 to $-20 \mathrm{mV}$ and corrected for leak current after application of $300 \mu \mathrm{M} \mathrm{Cd}{ }^{2+}$.

could be resolved best. Considering the small fraction of current to which the fits are made, it is doubtful that this time course is meaningfully different from the experiments with $200 \mathrm{nM} \omega$-AgaIVA (Fig. 9B)

\section{Kinetics in physiological $\mathbf{C a}^{2+}$}

All experiments described so far were performed with $\mathrm{Ba}^{2+}$ as charge carrier. Because of the strong dependence of blocking kinetics on $\mathrm{Ba}^{2+}$ concentration and ionic strength, it seemed important to define blocking kinetics in the different cell types by using a more physiological external solution. Therefore, a more limited series of experiments were performed using physiological saline containing $2 \mathrm{mM} \mathrm{Ca}^{2+}$ and $2 \mathrm{mM} \mathrm{Mg}^{2+}$.

The basic pattern of block by $\omega$-CTx-MVIIC studied with $\mathrm{Ca}^{2+}$ was the same as for $\mathrm{Ba}^{2+}$ solutions. Block in sympathetic neurons was potent, rapid, and rapidly reversible. In the experiment of Figure $11 \mathrm{~A}, 75 \mathrm{~nm}$ toxin blocked $55 \%$ of control current, and the time course of block could be fit well by a time constant of $2.5 \mathrm{sec} ; 10 \mu \mathrm{M}$ toxin blocked $77 \%$ of the current, and after removal of toxin, current recovered with a time constant of $10.5 \mathrm{sec}$. In four neurons studied with this protocol, $75 \mathrm{nM}$ toxin blocked $58 \pm 6 \%$ and $10 \mu \mathrm{M}$ toxin blocked $81 \pm 3 \%$ of control current. The mean time constant for block by $75 \mathrm{~nm}$ toxin was $2.0 \pm 0.3 \mathrm{sec}$, and the mean time constant for recovery was $10.0 \pm 0.3 \mathrm{sec}$. Assuming 1:1 binding, these values lead to a calculated $K_{\mathrm{d}}$ of $20 \mathrm{~nm}$ (Table 1).

The kinetics of toxin action on N-type channels in saline containing $2 \mathrm{mM} \mathrm{Ca}^{2+}$ and $2 \mathrm{mM} \mathrm{Mg}^{2+}$ is quite different from what would be predicted for a $\mathrm{Ba}^{2+}$ concentration of $4 \mathrm{~mm}$. Both the blocking and unblocking rates were significantly faster than with $\mathrm{Ba}^{2+}$ at 2-5 mм (Tablc 1 ), whereas the calculated $K_{\mathrm{d}}$ of $20 \mathrm{~nm}$ was similar to that for $2 \mathrm{mM} \mathrm{Ba}^{2+}$. It is intriguing that the unblocking rate with $\mathrm{Ca}^{2+}$ as charge carrier is faster than with $\mathrm{Ba}^{2+}$ in any ionic strength solution. The difference might reflect destabilization of bound toxin by calcium ions at the selectivity filter of the channel; however, this would not explain the faster blocking rates in the physiological solution. It is also not possible to rule out differential effects of the different monovalents used (mainly sodium in the physiological solution, mainly TEA in the $\mathrm{Ba}^{2+}$

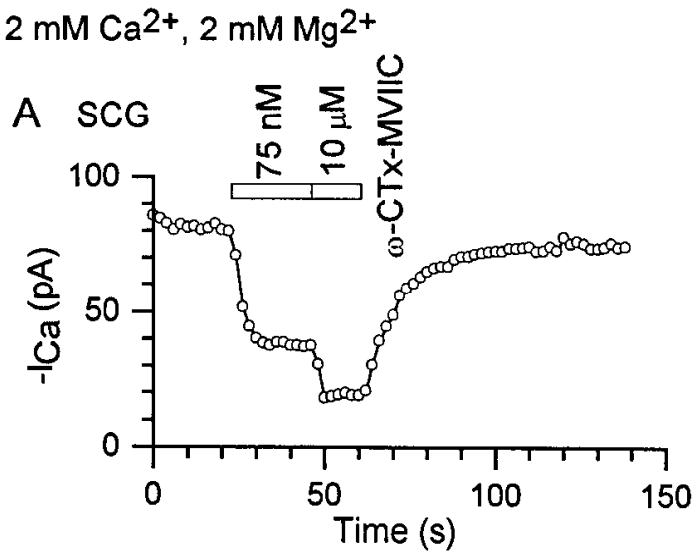

B Purkinje

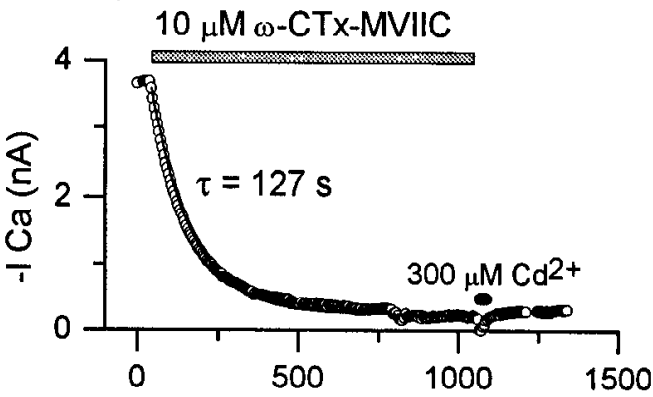

Time (s)

\section{C $\mathrm{CA3}$}

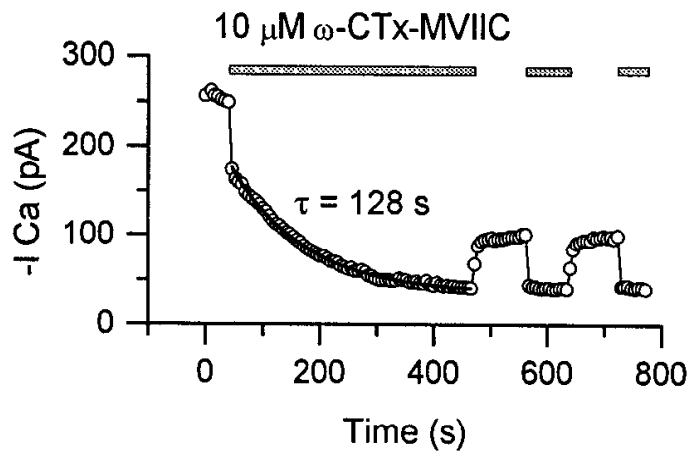

Figure 11. Kinetics of $\omega$-CTx-MVIIC block in physiological saline. A, Inhibition by $75 \mathrm{nM}$ and $10 \mu \mathrm{M} \omega$-CTx-MVIIC of $\mathrm{Ca}^{2+}$ current in an SCG neuron. Currents were elicited every $2 \mathrm{sec}$ by a $20 \mathrm{msec}$ pulse from -80 to $-10 \mathrm{mV}$. External solutions contained $10 \mu \mathrm{M}$ nimudipine. $B$. Inhibition of $\mathrm{Ca}^{2+}$ current in a Purkinje neuron. Currents were elicited every $5 \mathrm{sec}$ by a $20 \mathrm{msec}$ pulse from -80 to $+10 \mathrm{mV}$. External solutions contained $5 \mu \mathrm{M}$ nimodipine and $1 \mu \mathrm{M} \omega$-conotoxin-GVIA. $\mathrm{C}$, Inhibition of $\mathrm{Ca}^{2+}$ current in a CA3 neuron. Currents were elicited every $6 \mathrm{sec}$ by a $30 \mathrm{msec}$ pulse from -80 to $+20 \mathrm{mV}$. External solution: $2 \mathrm{mM} \mathrm{CaCl}, 2 \mathrm{mM} \mathrm{MgCl}, 1 \mathrm{mM}$ TEACl, $154 \mathrm{~mm} \mathrm{NaCl}, 10 \mathrm{~mm}$ glucose, $10 \mathrm{~mm}$ HEPES, $1 \mu \mathrm{M}$ tetrodotoxin, pH 7.4, adjusted with $\mathrm{NaOH}$.

solutions) or possible effects of solution composition on the configuration of the toxin molecule.

In Purkinje cells, current carried by $2 \mathrm{mM} \mathrm{Ca}^{2+}$ was blocked by $10 \mu \mathrm{M} \omega$-CTX-MVIIC with a slow time course and with essentially no reversibility after several minutes of washing (Fig. $11 B$ ). In five cells, the mean time constant for block by $10 \mu \mathrm{M} \omega$-CTx-MVIIC was $117 \pm 4 \mathrm{sec}$, approximately twofold slower than with $5 \mathrm{~mm}$ $\mathrm{Ba}^{2+}$. The slower kinetics with $\mathrm{Ca}^{2+}$ could be consistent with a surface charge mechanism if calcium ions bind with higher affinity 
than barium ions to specific sites associated with the surface charge.

Figure $11 C$ shows application of $10 \mu \mathrm{M} \omega$-CTx-MVIIC to a CA3 neuron studied with physiological saline. The pattern of block was identical to that with $5 \mathrm{~mm} \mathrm{Ba}^{2+}$, with both rapid and slow components of block. The relative magnitudes of the two fractions were similar to those with $\mathrm{Ba}^{2+}$. In four cells, the fast, reversible component was $27 \pm 3 \%$ of the overall current and the slow, poorly reversible component was $39 \pm 8 \%$. The average time constant for the slow block was $131 \pm 38 \mathrm{sec}$, similar to the value for block of P-type current in Purkinje neurons in physiological saline. The average time constant for recovery from the fast phase of block was $10 \pm 1 \mathrm{sec}$. This is identical to the time constant for recovery from block of N-type current in sympathetic neurons.

\section{DISCUSSION}

Our results show that $\omega$-CTX-MVIIC blocks at least three distinct types of calcium channels in rat neurons: $\omega$-conotoxin GVIAsensitive N-type channels, $\omega$-Aga-IVA-sensitive P-type channels, and channels in hippocampal CA3 neurons that are resistant to both $\omega$-conotoxin GVIA and $\omega$-Aga-IVA (as well as nimodipine). Block of $\mathrm{N}$-type channels is potent, rapid, and rapidly reversible, whereas block of P-type channels is potent, slow, and only very slowly reversible. The block of the nimodipine-, $\omega$-conotoxin GVIA-, and $\omega$-Aga-IVA-resistant component in hippocampal neurons has kinetics comparable to the slow block of P-type channels.

For both $\mathrm{N}$-type and P-type channels, the rate of block depended linearly on the concentration of $\omega$-CTX-MVIIC, consistent with 1:1 binding of toxin to the channel; however, the dissociation constant for $\omega$-CTx-MVIIC block of N-type channels calculated from on- and off-rate constants was consistently higher than the $\mathrm{EC}_{50}$ measured from equilibrium block. The reason for the discrepancy is not clear, but it raises the possibility that 1:1 binding is an oversimplification.

\section{Influence of solution composition}

For both N-type and P-type channels, the rate of block by $\omega$-CTXMVIIC was influenced powerfully by the concentration of $\mathrm{Ba}^{2+}$ in the external solution. Blocking kinetics could also be changed by altering the ionic strength of the external solution with monovalent ions. It is likely that these effects are attributable, at least partly, to screening of a negative surface charge near the binding site for $\omega$-CTX-MVIIC. There may also be competition between divalent ions and the toxin molecule for binding to specific sites, perhaps including the mouth of the pore.

Whatever the molecular interpretation, the powerful effect of solution composition on blocking rate is an important experimental variable in using the toxins. For example, block of P-type channels is so slow at $\mathrm{Ba}^{2+}$ concentrations of $25 \mathrm{~mm}$ or higher that block by even $10 \mu \mathrm{M}$ toxin is not distinguished easily from spontaneous run-down of current. Even with $5 \mathrm{mM} \mathrm{Ba}^{2+}$, block by $1 \mu \mathrm{M}$ is very slow $(\tau \sim 8-10 \mathrm{~min})$. This caused us to underestimate the potency of $\omega$-CTX-MVIIC block of P-type channels in early experiments (Hillyard et al., 1992).

Radiolabeled $\omega$-CTx-MVIIC binds to rat brain membranes with high affinity, being displaced by cold $\omega$-CTx-MVIIC with an $\mathrm{IC}_{50}$ of $\sim 0.1-1$ nм (Hillyard et al., 1992; Adams et al., 1993). Consistent with our results, the $\mathrm{IC}_{50}$ for displacement was lower in low ionic strength solutions (Hillyard et al., 1992). The rough estimate of $0.5 \mathrm{~nm}$ that we make for binding of $\omega$-CTx-MVIIC to P-type channels in low ionic strength solution (Table 1) is comparable to that of the high-affinity binding site in membranes.

\section{Comparison with other neurons}

In a detailed pharmacological study of calcium channels in cultured cerebellar granule neurons, Randall and Tsien (1995) found that $\omega$-CTX-MVIIC inhibited most but not all of the current remaining in the presence of nimodipine and $\omega$-conotoxin GVIA. The time course of inhibition was slow, similar to the slow block of all non-GVIA-sensitive components that we saw in hippocampal CA3 neurons. Randall and Tsien found that $\omega$-CTx-MVIIC (applied in the presence of $\omega$-conotoxin GVIA) blocks a similar fraction of current as does $1 \mu \mathrm{M} \omega$-Aga-IVA. Similarly, in guinea pig dentate gyrus granule neurons, Eliot and Johnston (1994) found no clear evidence for additional block when $\omega$-CTx-MVIIC was applied in the presence of nimodipine, $\omega$-conotoxin GVIA, and $1 \mu \mathrm{M} \omega$-Aga-IVA. In contrast, in six of eight CA3 neurons we saw additional current blocked by $\omega$-CTx-MVIIC applied in the presence of $1 \mu \mathrm{M} \omega$-Aga-IVA and $\omega$-conotoxin. The comparison suggests, at the least, somewhat different combinations of $\omega$-AgaIVA-sensitive and $\omega$-CTX-MVIIC-sensitive current types in different types of neurons. In CA3 neurons, we can distinguish at least three components of $\omega$-CTX-MVIIC-sensitive current: the fast component that is occluded by $\omega$-conotoxin GVIA, presumably though N-type channels, a slowly blocked component that is also blocked by $200 \mathrm{nM} \omega$-Aga-IVA, and a slowly blocked component that is resistant to $\omega$-Aga-IVA at concentrations up to $1 \mu \mathrm{M}$. It is possible that much of the current fraction blocked by both $\omega$-AgaIVA and $\omega$-CTX-MVIIC in CA3 neurons has the properties of Q-type current, as described by Randall and Tsien (1995) in cerebellar granule neurons, because $200 \mathrm{~nm} \omega$-Aga-IVA would inhibit the great majority of a component sensitive to $\omega$-Aga-IVA with a $K_{\mathrm{d}}$ of $\sim 90 \mathrm{nM}$. It would be difficult to test lower concentrations of $\omega$-Aga-IVA on CA3 neurons, because the kinetics of block even for $200 \mathrm{nM}$ is slow and the fraction blocked is smaller than for other neurons. $\omega$-Aga-IVA at $200 \mathrm{~nm}$ blocks much more slowly in CA3, CA1, and dorsal root ganglion neurons than in Purkinje neurons or spinal cord neurons (Mintz et al., 1992a), which is consistent with the $\omega$-Aga-IVA-sensitive channels in CA3 neurons being distinct from the P-type channels in Purkinje neurons. Whether the component in CA3 neurons blocked by both $\omega$-Aga-IVA and $\omega$-CTx-MVIIC is classified as P-type or Q-type, there is an additional component sensitive only to $\omega$-CTX-MVIIC that is blocked with similar slow kinetics.

\section{Comparison with cloned channels}

Channels formed by $\alpha_{1 \mathrm{~B}}$ subunits are potently blocked by $\omega$-conotoxin GVIA (Williams et al., 1992; Fujita et al., 1993; Stea et al., 1993), as are native $\mathrm{N}$-type channels. The potency of block by $\omega$-CTx-MVIIC is similar between channels formed by $\alpha_{1 \mathrm{~B}}$ subunits (half-blocking concentration 5-10 nM, $5 \mathrm{mM} \mathrm{CaCl}$; Grantham et al., 1994) and native N-type channels $\left(\mathrm{EC}_{50} 18 \mathrm{nM}\right.$, $5 \mathrm{mM} \mathrm{BaCl}_{2}$ ). Also, the block of $\alpha_{1 \mathrm{~B}}$ channels by $\omega$-CTx-MVIIC reversed relatively rapidly ( $\tau_{\text {off }} \sim 10 \mathrm{~min}$ ), although more slowly, than native $\mathrm{N}$-type channels in sympathetic neurons $\left(\tau_{\text {off }} \sim 0.5\right.$ $\min )$.

Channels formed by the $\alpha_{1 \mathrm{~A}}$ subunit expressed in oocytes are also sensitive to block by $\omega$-CTx-MVIIC (Sather et al., 1993; Zhang et al., 1993, Stea et al., 1994; DeWaard and Campbell, $1995)$ but with slow kinetics. The kinetics of block is even slower ( $\tau_{\text {on }} \sim 150 \mathrm{sec}$ with $5 \mu \mathrm{M} \omega$-CTX-MVIIC in $2 \mathrm{mM} \mathrm{Ba}^{2+}$; Sather et al., 1993) than we found for block of native P-type channels 
( $\tau_{\text {on }} \sim 35 \mathrm{sec}$ with $2 \mu \mathrm{M}$ toxin in $2 \mathrm{mM} \mathrm{Ba}^{2+}$ ), and if anything, the reversal is also even slower than for native P-type channels. The upper limit for the $K_{\mathrm{d}}$ estimated by Sather et al. (1993) for $\alpha_{1 \mathrm{~A}}$ channels $(150 \mathrm{~nm})$ is consistent with our estimation of $50 \mathrm{~nm}$ for P-type channels in Purkinje neurons, considering that both are rough estimates because of the slow equilibrium. The $K_{\mathrm{d}}$ for the slowly blocked component in cerebellar granule neurons is probably in the same range, because preincubation of $500 \mathrm{nM} \omega$-CTxMVIIC prevented the acute effects of $5 \mu \mathrm{M} \omega$-CTx-MVIIC (Randall and Tsien, 1995). Overall, the potency and kinetics of $\omega$-CTXMVIIC on expressed $\alpha_{1 \mathrm{~A}}$ subunits seem similar to its effects on both P-type channels in Purkinje neurons and on the slowly blocked components in hippocampal and cerebellar granule neurons.

It has becn suggested that $\alpha_{1 \mathrm{~A}}$ subunits may form both P-type calcium channels in cerebellar Purkinje neurons (Stea et al., 1994) and Q-type channels in cerebellar granule neurons (Randall and Tsien, 1995). Differences in the currents may reflect alternatively spliced $\alpha_{1 \mathrm{~A}}$ subunits or different auxiliary subunits. A reasonable working hypothesis is that $\omega$-CTx-MVIIC blocks all channels formed by subunits from the $\alpha_{1 \mathrm{~B}}$ and $\alpha_{1 \mathrm{~A}}$ branches of the calciumchannel family tree. These two branches are more closely related to each other than to other $\alpha$ subunits (Snutch and Reiner, 1992; Horne et al., 1993), and the regions of homology may include a binding site for $\omega$-CTX-MVIIC. It is interesting that members of these two families also seem to share functional similarities in mediating synaptic transmission and in being modulated in similar ways by G-protein-linked receptors (Mintz and Bean, 1993; Wheeler et al., 1994; Wu and Saggau, 1995b).

\section{$\omega$-CTX-MVIIC-sensitive calcium channels in synaptic transmission}

$\omega$-CTx-MVIIC can completely inhibit synaptic transmission at CA3-CA1 synapses (Lovinger et al., 1994; Wheeler et al., 1994; $\mathrm{Wu}$ and Saggau, 1995a). By recording calcium transients in terminals from C 13 neurons, Wu and Saggau (1995a) have distinguished three components of calcium entry blocked by $\omega$-CTx-MVIIC: one that is also blocked by $\omega$-conotoxin GVIA, one that is also blocked by $\omega$-Aga-IVA, and one that is resistant to both $\omega$-conotoxin GVIA and $\omega$-Aga-IVA (at $1 \mu \mathrm{M}$ ). These components match well with our results on calcium current in dissociated CA3 neurons. The correspondence gives support to the idea that in CA3 neurons $\omega$-CTx-MVIIC can block a current resistant to saturating concentrations of $\omega$-Aga-IVA and $\omega$-conotoxin GVIA, as well as the channels sensitive to these agents.

Although $\omega$-CTx-MVIIC is not as selective as $\omega$-Aga-IVA in discriminating among types of channels, its ability to block functionally related channels involved in transmitter release should make it a useful tool in further studies on synaptic transmission. It should also be useful in studies on cell bodies when blocking as much voltage-dependent calcium entry as possible is desired; the combination of $\omega$-CTX-MVIIC and nimodipine should block $80-90 \%$ of the high-threshold current in most types of neurons.

\section{REFERENCES}

Adams ME, Myers RA, Imperial JS, Olivera BM (1993) Toxityping rat brain calcium channels with $\omega$-toxins from spider and cone snail venoms. Biochemistry 32:12566-12570.

Bernheim L, Beech DJ, Hille B (1991) A diffusible second messenger mediates one of the pathways coupling receptors to calcium channels in rat sympathetic neurons. Neuron 6:859-867.
Boland LM, Morrill JM, Bean BP (1994) $\omega$-Conotoxin block of N-type calcium channels in frog and rat sympathetic neurons. J Neurosci 8:5011-5027.

DeWaard M, Campbell KP (1995) Subunit regulation of the neuronal $\alpha_{1 \mathrm{~A}} \mathrm{Ca}^{2+}$ channel expressed in Xenopus oocytes. J Physiol (Lond) 485:619-634.

Ellinor PT, Yang J, Sather W, Zhang J-F, Tsien RW (1995) $\mathrm{Ca}^{2+}$ channel selectivity at a single locus for high-affinity $\mathrm{Ca}^{2+}$ interactions. Neuron 15:1121-1132.

Elmslie KS, Kammermeier PJ, Jones SW (1994) Reevaluation of $\mathrm{Ca}^{2+}$ channel types and their modulation in bullfrog sympathetic neurons. Neuron 13:217-228.

Fujita Y, Mynlieff M, Dirksen RT, Kim M-S, Niidome T, Nakai J, Friedrich T, Iwabe N, Miyata T, Furuichi T, Furutama D, Mikoshiba K, Mori Y, Beam KG (1993) Primary structure and functional expression of the $\omega$-conotoxin-sensitive $\mathrm{N}$-type calcium channel from rat brain. Neuron 10:585-598.

Furshpan EJ, Potter DD (1989) Seizure-like activity and cellular damage in rat hippocampal neurons in cell culture. Neuron 3:199-207.

Grantham CJ, Bowman D, Bath CP, Bell DC, Bleakman D (1994) $\omega$-Conotoxin MVIIC reversibly inhibits a human N-type calcium channel and calcium influx into chick synaptosomes. Neuropharmacology 33:255-258.

Hamill OP, Marty A, Neher E, Sakmann B, Sigworth FJ (1981) Improved patch-clamp techniques for high-resolution current recording from cells and cell-free membrane patches. Pflügers Arch 391:85-100.

Hillyard DR, Monje VD, Mintz IM, Bean BP, Nadasdi L, Ramachandran J, Miljanich G, Azimi-Zoonooz A, McIntosh JM, Cruz LJ, Imperial JS, Olivera BM (1992) $\Lambda$ new Conus peptide ligand for mammalian presynaptic $\mathrm{Ca}^{2+}$ channels. Neuron 9:69-77.

Horne WA, Ellinor PT, Inman I, Zhou M, Tsien RW, Schwarz TL (1993) Molecular diversity of $\mathrm{Ca}^{2+}$ channel subunits from the marine ray Discopyge ommata. Proc Natl Acad Sci USA 90:3787-3791.

Jones SW, Marks TN (1989) Calcium currents in bullfrog sympathetic neurons. I. Activation kinetics and pharmacology. J Gen Physiol 94:151-167.

Kiskin NI, Krishtal OA, Tsydrenko AY (1990) Cross-desensitization reveals pharmacological specificity of excitatory amino-acid receptors in isolated hippocampal neurons. Eur J Neurosci 2:461-470.

Kostyuk PG, Mironov SSL, Doroshenko PA, Ponomarev VN (1982) Surface charges on the outer side of mollusc neuron membrane. J Membr Biol 70:171-179.

Kuo C-C, Hess P (1993) Characterization of the high-affinity $\mathrm{Ca}^{2+}$ binding sites in the L-type $\mathrm{Ca}^{2+}$ channel pore in rat $\mathrm{PC} 12$ cells. J Physiol (Lond) 466:657-682.

Lovinger DM, Merritt A, Reyes D (1994) Involvement of N- and non$\mathrm{N}$-type calcium channels in synaptic transmission at corticostriatal synapses. Neuroscience 62:31-40.

Mintz IM, Bean BP (1993) $\mathrm{GABA}_{\mathrm{B}}$ receptor inhibition of P-type $\mathrm{Ca}^{2+}$ channels in central neurons. Neuron 10:889-898.

Mintz IM, Adams ME, Bean BP (1992a) P-type calcium channels in central and peripheral neurons. Neuron $9: 1-20$.

Mintz IM, Venema VJ, Swiderek K, Lee T, Bean BP, Adams ME (1992b) P-type calcium channels blocked by the spider toxin $\omega$-Aga-IVA. Nature 355:827-829.

Olivera BM, McIntosh JM, Cruz LJ, Luque FA, Gray WR (1984) Purification and sequence of a presynaptic peptide toxin from Conus geographus venom. Biochemistry 23:5087-5090.

Randall A, Tsien RW (1995) Pharmacological dissection of multiple types of $\mathrm{Ca}^{2+}$ channel currents in rat cerebellar granule neurons. J Neurosci 15:2995-3012.

Regan LJ, Sah DWY, Bean BP (1991) $\mathrm{Ca}^{2+}$ channels in rat central and peripheral neurons: high-threshold current resistant to dihydropyridine blockers and $\omega$-conotoxin. Neuron 6:269-280.

Sather WA, Tanabe T, Zhang J-F, Mori Y, Adams ME, Tsien RW (1993) Distinctive biophysical and pharmacological properties of class $\Lambda$ (BI) calcium channel $\alpha 1$ subunits. Neuron 11:291-303.

Snutch TP, Reiner PB (1992) $\mathrm{Ca}^{2+}$ channels: diversity of form and function. Curr Opin Neurobiol 2:247-253.

Stea A, Dubel SJ, Pragnell M, Leonard JP, Campbell KP, Snutch TP (1993) A $\beta$-subunit normalizes the electrophysiological properties of a cloned $\mathrm{N}$-type $\mathrm{Ca}^{2+}$ channel $\alpha 1$ subunit. Neuropharmacology 32:1103-1116.

Stea A, Tomlinson WJ, Soong TW, Bourinet E, Dubel SJ, Vincent SR, Snutch TP (1994) Localization and functional properties of rat brain $\alpha_{1 \mathrm{~A}}$ calcium channel reflect similarities to neuronal Q- and P-type channels. Proc Natl Acad Sci USA 91:10576-10580. 
Swartz KJ, Bean BP (1992) Inhibition of calcium channels in rat CA3 pyramidal neurons by a metabotropic glutamate receptor. J Neurosci 12:4358-4371.

Wheeler DB, Randall A, Tsien RW (1994) Roles of N-type and Q-type $\mathrm{Ca}^{2+}$ channels in supporting hippocampal synaptic transmission. Science 264:107-111.

Williams ME, Brust PF, Feldman DH, Saraswathi P, Simerson S, Maouf A, McCue AF, Velicelebi G, Ellis SB, Harpold MM (1992) Structure and functional expression of an $\omega$-conotoxin-sensitive human $\mathrm{N}$-type calcium channel. Science 257:389-395.

Wilson DL, Morimoto K, Tsuda Y, Brown AM (1983) Interaction between calcium ions and surface charge as it relates to calcium currents. J Membr Biol 72:117-130.
Wu L-G, Saggau P (1995a) Block of multiple presynaptic calcium channel types by $\omega$-conotoxin MVIIC at hippocampal CA 3 to CA1 synapses. J Neurophysiol 73:1965-1972.

Wu L-G, Saggau P (1995b) GABA B $_{B}$ receptor-mediated presynaptic inhibition in guinea-pig hippocampus is caused by reduction of presynaptic $\mathrm{Ca}^{2+}$ influx. J Physiol (Lond) 485:649-657.

Zhang JF, Randall AD, Ellinor PT, Horne WA, Sather WA, Tanabe T, Schwarz TL, Tsien RW (1993) Distinctive pharmacology and kinetics of cloned neuronal $\mathrm{Ca}^{2+}$ channels and their possible counterparts in mammalian CNS neurons. Neuropharmacology 32:1075-1088.

Zhou W, Jones SW (1995) Surface charge and calcium channel saturation in bullfrog sympathetic neurons. J Gen Physiol 105:441-462. 